\title{
RESEARCH
}

\section{The third person gap in adnominal pronoun constructions}

\author{
Georg F. K. Höhn \\ Georg-August-Universität Göttingen, Sprachwissenschaftliches Seminar, Käte-Hamburger-Weg, Göttingen, DE \\ georg.hoehn@uni-goettingen.de
}

\begin{abstract}
The lack of third person adnominal pronouns in English-type languages ( ${ }^{*}$ they linguists) is argued to be an effect of contextually conditioned allomorphy between the exponents of the definite article and third person pronouns within a pronominal determiner structure. A crosslinguistic survey of 82 languages finds that the third person gap is crosslinguistically relatively rare and may be restricted to Europe and surrounding areas. The survey also suggests a potential interaction between the third person gap and the availability of distinct articles, as expected on the proposed analysis. The paper also discusses issues raised by the third person gap for alternative analyses, including those advocating an NP-analysis.
\end{abstract}

Keywords: pronominal determiners; person; articles; adnominal pronouns; contextually conditioned allomorphy; DP vs. NP

\section{Introduction}

English adnominal pronoun constructions (APCs) like (1a) are notoriously excluded in the third person (1b). Expanding on previous intuitions, this paper offers a morphosyntactic analysis of this gap and discusses its implications for nominal structure in a crosslinguistic perspective.
a. we/you linguists
b. *they linguists

English has (at least) three different constructions that might be characterised as involving adnominal pronouns, listed in (2). I use the term APC to refer to constructions like (2a) only.
a. we linguists
b. we the linguists
c. we, (the) linguists

Expressions like (2b) are more restricted than plain APCs, being degraded as objects (3a), in the scope of focus-sensitive particles (3b) or as restrictor of a quantifier (3c). They also seem to be strongly marked in the second person (3d) and while English first person plural APCs exceptionally allow the object form of the pronoun to be used in subject position (4a), this option is excluded in the construction involving the article (4b). While the analysis of this construction raises important questions of its own, it clearly differs from APCs like (2a) and I will not further deal with it here. 
a. Everyone loves us (??the) linguists.

b. Even we (?the) linguists need to relax sometimes.

c. Some of us (*the) linguists are easy to anger.

d. If only you (*the) linguists could follow directions.

(4) a. We/us linguists are concerned with the truth.

b. We/*us the linguists are concerned with the truth.

The construction in (2c) involves a loose apposition, often marked by a slight intonational break after the pronoun and a comma in conventional orthography. Section 2.2 will be concerned with distinguishing APCs from constructions like (2c) and close apposition (the poet Burns).

An important concern in the literature on APCs has been the question of whether their structure parallels expressions with a definite article, as suggested prominently by the pronominal determiner analysis (PDA) going back to Postal (1969) and Abney (1987) sketched in (5), or whether a different structure is involved, e.g. apposition (6).

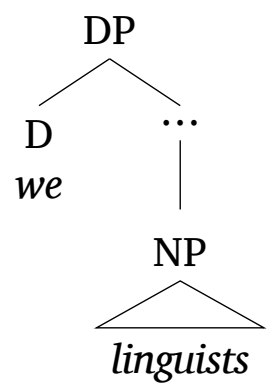

(6)

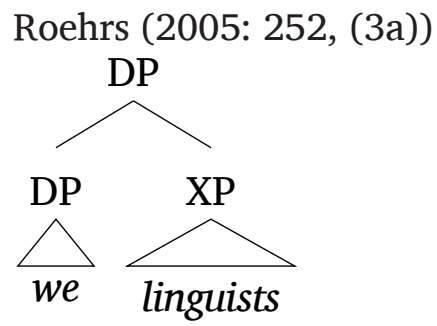

Crosslinguistic variation in APCs has recently received more systematic attention (Choi 2013; 2014a; Louagie \& Verstraete 2015; Höhn 2016; 2017; cf. also earlier observations by Pesetsky 1978). The main focus of this paper is on English-type APCs and I am going to argue in favour of a PDA and against appositive or other alternative analyses for these, but I will also point out reasons for assuming that there are other languages in which APCs are likely to involve different types of structures.

The third person gap in languages like English is explained as an effect of contextually conditioned allomorphy between the exponents of the definite article and third person pronouns within the framework of Distributed Morphology (Halle \& Marantz 1993; Embick 2010). Extending this approach beyond English, languages displaying the third person gap in APCs are expected to also have a distinct article. This prediction is shown to be largely borne out in a typological survey of about 80 languages. On the proposed account, the English-type third person gap is contingent on a particular interaction of structural configuration and morphological exponence, so the exclusion of third person APCs is not necessarily expected to be particularly common and definitely not a universal pattern, considering languages vary in their APC structure and, of course, their systems of 
morphological exponence. This is again borne out, although the survey also raises previously unnoticed questions concerning a subset of languages.

The proposal analyses the pronoun as head of the APCs in line with the DP hypothesis (Abney 1987). While I do not exclude the possibility of an NP-based analysis of APCs in principle, I present some challenges for such an approach at the end of the paper.

The article is organised as follows. Section 2 discusses arguments for a pronominal determiner analysis of English-type APCs and sketches data from some languages with different APC structures. A PF-based analysis of the third person gap in languages like English is presented in Section 3. In Section 4, I discuss the crosslinguistic survey on the third person gap and its proposed connection to the availability of a distinct definite article, showing that the third person gap is not a very common phenomenon. Potential issues for alternative approaches to English-type APC structure are addressed in Section 5. Section 6 concludes the paper.

\section{Adnominal pronouns}

This section sketches the main analyses proposed for APCs, focusing on English-type languages with a third person gap. Sections 2.1 and 2.2 provide arguments against an appositive analysis and in favour of treating the adnominal pronoun as a determiner in such languages. Section 2.3 sketches some points of APC variation that are relevant to the later discussion.

\subsection{Analysing English adnominal pronouns}

A central point of contention for the analysis of English-type APCs has been the relationship between the pronoun and the noun, or the remainder of the noun phrase. One strand of analyses suggests that the pronoun and the noun form two distinct nominal phrases in an appositive structure (Delorme \& Dougherty 1972; Olsen 1991; Cardinaletti 1994; Willim 2000; Rutkowski 2002; Ackema \& Neeleman 2013; 2018). Since this type of approach makes no claims about the category of the phrases in apposition, nor about a direct relationship between pronouns and articles, the DP/NP debate is tangential on this view. An appositive analysis of APCs may view them as a complex DP involving a pronominal DP with an appositive phrase (either a DP or a smaller projection) containing the noun as sketched by Roehrs (2005: 252, (3a)) reproduced in (7), but it could also be framed in terms of apposition of two NPs (8), cf. Delorme \& Dougherty (1972).

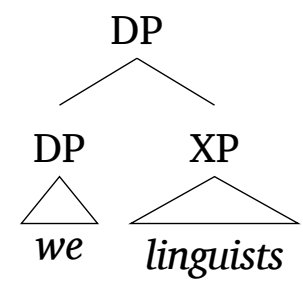

(8)

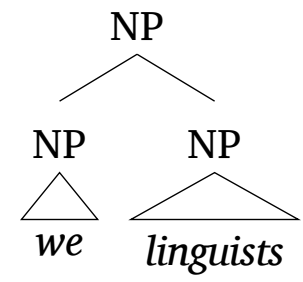

The major alternative is the pronominal determiner analysis (PDA) based on Postal (1969). On this view, APCs structurally parallel definite expressions like the linguists, so adnominal pronouns are essentially articles. A central argument for the PDA, reflected by its name, 
is the complementary distribution of definite articles and adnominal pronouns already illustrated in (3) for English and in (9) for German.

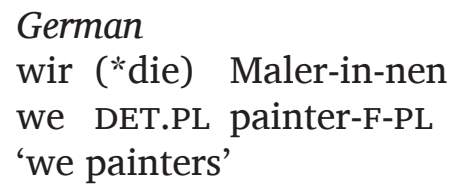

Since Abney's (1987) reanalysis of Postal's proposal in terms of the DP-hypothesis, all PDA-based approaches to adnominal pronouns I am aware of follow suit in treating the pronoun as head of the construction (Lawrenz 1993; Longobardi 1994; 2008; Lyons 1999; Panagiotidis 2002; Rauh 2003; 2004; Roehrs 2005; Saab 2007; 2013; Bernstein 2008b; Höhn 2016), as sketched in (10) leaving aside other possible functional projections.

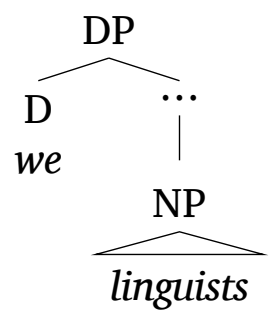

A final set of approaches assumes that the pronoun in APCs occupies a specifier position (e.g. Spec,DP), often moved there after first establishing a predication relation with the noun lower in the structure. These approaches are relatively heterogeneous in their specifics, but it is worth noting that those I am aware of are (mainly) based on Japanese (Noguchi 1997; Furuya 2008; Inokuma 2009) or Greek (Panagiotidis \& Marinis 2011; Choi 2014a; b), although at least Choi (2014a; b) proposes to also extend his analysis to English. I will return to this class of analyses in Section 2.3 and focus for now on reasons for considering the pronoun to be the head of an English-type APCs and against assuming an appositive analysis.

A first argument that APCs are headed by the pronoun determining grammatical properties of the overall phrase, particularly its grammatical person, is based on Lyons (1999: 312f.) and Radford (2009: 109). Reflexives generally agree in person with their antecedent. In (11a) the person of the nominal expression, requiring the use of the second person reflexive, is not determined by the noun lecturers, which is identical across all examples. Instead, the second person property of the nominal phrase stems from the second person plural pronoun you. Determining the grammatical properties of a constituent is typically what is expected of a head.

(11) a. You lecturers always disgrace yourselves/*themselves.

b. The lecturers always disgrace *yourselves/themselves.

c. Some lecturers always disgrace *yourselves/themselves.

d. Lecturers always disgrace *yourselves/themselves.

A similar argument can be made based on verbal agreement in German. The noun Linguisten 'linguists' is constant across the German data in (12). The agreement marking on the verb is therefore unlikely to be sensitive to a property of the noun in the APC in (12a), but rather to the person specification encoded by the pronoun. In this respect, then, the pronoun determines the (relevant) grammatical properties of the whole phrase. 


\section{German}

a. Ihr Linguisten singt/ *singen schön.

you.PL linguists sing.2PL sing.3PL beautifully

'You linguists sing beautifully.'

b. Die Linguisten *singt/ singen schön.

DET.PL linguists sing.2PL sing.3PL beautifully

'The linguists sing beautifully.'

c. Linguisten *singt/ singen schön.

linguists sing.2PL sing.3PL beautifully

'Linguists sing beautifully.'

A potential challenge for this view comes from so-called unagreement (e.g. Hurtado 1985; Ackema \& Neeleman 2013; 2018; Choi 2013; 2014a; Höhn 2016). In languages like Spanish or Modern Greek definite plural noun phrases can co-occur with non-third person verbal marking, cf. (13).
Spanish (after Hurtado 1985: 187, (1))
Las mujeres denunciamos las injusticias.
DET.PL women denounced.1PL DET.PL injustices
'We women denounced the injustices.'

This may seem to suggest that a pronoun is not necessarily involved in triggering agreement after all. Indeed, Ackema \& Neeleman $(2013 ; 2018)$ argue for a symmetric account of agreement based on unagreement. Simplifying a lot, they propose that the person features of the verb are transferred to R-expression subjects through a combination of processes of Feature Spreading and Dissociation. I won't discuss their analysis in detail (but see Section 2.3), but it is worth noting that Ackema \& Neeleman are compelled to assume an appositive analysis of APCs (Ackema \& Neeleman 2018: 294f.). So even an alternative view on the agreement mechanism underlying data like (13) has (so far) not led to a noun-headed version of the PDA, but to appositive analyses. The next subsection provides some arguments for the PDA over an appositive analysis of English-style APCs.

\subsection{Some arguments against appositive analyses}

Pesetsky (1978), Lawrenz (1993: Chapter 6), Roehrs (2005) and Höhn (2016) provide a range of arguments against analysing APCs in languages like English or German as instances of apposition. I present a selection here.

A distinction is often made between loose and close apposition, the most salient difference being that the latter "occur within a single prosodic unit, whereas loose appositives involve an intonational break between the two subparts" (Lekakou \& Szendrôi 2012: 111, fn. 6). ${ }^{1}$ This provides an initial argument against analysing English-style APCs as loose apposition, since they do not normally display such an intonational break. Furthermore, Pesetsky (1978: 355, (17)) notes that the exceptional use of us in subject positions noted for APCs in (4a) is not possible with apposition, cf. (14). ${ }^{2}$

(14) a. We, linguists from conviction, abhor computers.

b. *Us, linguists from conviction, abhor computers.

\footnotetext{
${ }^{1}$ See Burton-Roberts (1975) and Lekakou \& Szendrői (2007; 2012) for more details.

${ }^{2}$ For a possible analysis of the case alternation in English APCs see Parrott (2009).
} 
Drawing on Höhn (2016: 563, (45)), example (15a) shows that quantified expressions can be used in loose apposition to pronouns, while being ruled out with APCs (15b) and a definite article (15c).

(15) a. we/you/they, (that is) some students from Colchester

b. *we/you/they some students from Colchester

c. *the some students from Colchester

Lawrenz (1993: 90) argues that coordinated noun phrases in German can only occur in APCs when a definite article could appear instead of the pronoun, while appositions display no such restrictions. Although I think her argument is correct, additional clarification is required for its application to German and English. In both languages, coordinated plural noun phrases are unproblematic with apposition (16/17a), APCs (16/17b) and definite expressions (16/17c). Coordinate structures consisting of two singular noun phrases referring to individuals can occur in loose apposition to a plural pronoun (16/17d), but not in an APC (16/17e).
a. wir, Väter und Söhne
b. wir Väter und Söhne
c. die Väter und Söhne
d. wir, Vater und Sohn
e. *wir Vater und Sohn
f. *die Vater und Sohn

(17) a. we, fathers and sons

b. we fathers and sons

c. the fathers and sons

d. we, father and son

e. *we father and son

f. the father and son

Extending Lawrenz' original argument to English is complicated by the fact that a definite counterpart to (17e) is grammatical after all, cf. (17f). This phrase is ambiguous between what Heycock \& Zamparelli (2005) call a joint reading, referring to a single individual who is both a father and a son, and a split reading, referring to a non-singleton set of a father and his son. German lacks a singular split reading (Heycock \& Zamparelli 2005), but (18) is a (well-formed, pace Lawrenz 1993) joint reading counterpart to (17f) with a singular determiner instead of the plural form from (16f). To rescue Lawrenz' generalisation, one needs to understand why English (17e) cannot have a split or joint reading and why the grammaticality of German (18) does not imply the grammaticality of the APC in (16e).

$$
\begin{array}{ll}
\text { der } & \text { Vater und Sohn } \\
\text { DET.NOM.SG } & \text { father and son }
\end{array}
$$

The split reading of (17f) is (partly) dependent on the lack of number on the (Heycock \& Zamparelli 2005). A split reading of (17e) is probably ruled out because plural determiners in English require formal number agreement with a plural nominal expression (the [ + PLUR] feature of Heycock \& Zamparelli 2005) and a coordinate structure of two singular nouns is not formally plural marked. Thus, *we father and son is out for the same reasons as *these/those father and son and the German examples in (16ef). 
A joint reading is ruled out for both (16e) and (17e) by the fact that the pronoun is semantically plural, while the joint coordination would have a singular referent. ${ }^{3}$ However, as a joint reading would be notionally and grammatically singular, it might be expected to be available with a singular pronominal determiner. In English, this is ungrammatical (*I father and son) for the same reasons that generally exclude argumental singular APCs ("I/you student). ${ }^{4}$ German (18), however, has a singular APC counterpart (19a) with a joint reading only. The lack of a split reading for this construction with APCs or plain articles is illustrated in (19bc), where identity of the referents of the coordinated nouns leads to infelicity or ungrammaticality.
a. ich Vater und Sohn
I father and son
approximately: 'I being a father and a son'
b. *ich Ehefrau und Ehemann
I wife and husband
c. *die/ der Ehefrau und Ehemann
DET.NOM.SG.F DET.NOM.SG.M wife and husband intended: 'the wife and husband'

While the data in (16/17) serve to distinguish APCs from loose apposition, the data in (18) and (19) illustrate Lawrenz' general proposal that coordinated noun phrases can only occur in an APC if a definite article could be used instead. The apparent counterexample in (17f) is due to the availability of split readings with non-plural marked determiners discussed by Heycock \& Zamparelli (2005) and does not carry over to the (plural marked) pronominal determiner in (17e).

I now turn to some arguments against treating APCs as instances of close apposition. Classically, close appositions are taken to contain a proper name (Burton-roberts 1975: 397), clearly not a requirement in APCs. Lekakou \& Szendrói (2012) do not assume this strong restriction for their analysis of Greek constructions involving two coreferential nominal expressions, cf. also Stavrou (1995), but agree that the order of close apposition is reversible (see also Burton-Roberts 1975: 402 and Payne \& Huddleston 2002: 447). In these constructions, agreement is with either part of the apposition (20ab). Importantly, Lekakou \& Szendrói (2012) also note that this is not the case for Greek APCs (20c), where person agreement is fixed and the pronoun obligatorily comes first (see also Section 2.3). This observation also holds for English, cf. the ungrammaticality of *academics we.

Greek (Lekakou \& Szendrői 2012: 114, (12))
a. O aetos to puli ine megaloprepos/ megaloprepo. DET.M eagle DET.N bird is majestic.M majestic.N
b. To puli o aetos ine megaloprepo/ megaloprepos. DET.N bird DET.M eagle is majestic.N majestic.M 'The eagle that is a bird is majestic.'
c. Emis i glosoloji piname/ *pinane. we DET.PL linguists are.hungry.1PL are.hungry.3PL 'We linguists are starving/hungry.'

\footnotetext{
${ }^{3}$ Leaving aside majestic and nurse we, either we itself refers to a plurality or, on Heim's (2008) proposal that phi-features introduce presuppositions on the reference sets of their complements, it requires that its complement refer to a plurality.

${ }^{4}$ The actual reason for this restriction remains unclear, see Section 2.3.
} 
The argumentation against a loose appositive analysis from (17) can be adapted to close apposition as well. Two coordinated proper names can serve as close apposition (21a). If APCs were simply close apposition, replacing the anchor the siblings with a plural pronoun should yield a grammatical APC, contrary to fact (21b). On the other hand, replacing only the definite article with a pronoun as in (21c) leads to a well-formed APC, as expected if English adnominal pronouns are pronominal determiners.

(21) a. The siblings Hänsel and Gretel were abandoned in the woods.

b. *We/us/you Hänsel and Gretel were abandoned in the woods

c. We/us/you siblings Hänsel and Gretel were abandoned in the woods.

Roehrs (2005) provides another argument against assimilating APCs to close apposition in German. APCs can contain adjectival modifiers (22a), whereas the second part of an apposition cannot be modified, cf. (22b). Höhn (2016: 563) notes that this reasoning also applies to English, cf. (23a) vs. (23bc).

(22) German
a. wir schlauen Kinder
we clever kids
b. after Roehrs (2005: 255, (7a))
meine Freundin (*liebe) Maria
my girl-friend dear Maria
'my friend (*dear) Maria'

(23) a. [you] [famous poets], [we/us] [clever kids]

b. *[the poet] [skillful Burns], *[the number] [interesting 5]

c. [the famous poet] [Burns], [the interesting number] [5]

These observations support the view that APCs should not be analysed as loose or close apposition in languages like English and German.

\subsection{Variation in APCS}

This section addresses selected aspects of crosslinguistic variation in the structure of APCs (for a wider overview see Pesetsky 1978; Choi 2013; 2014a; Louagie \& Verstraete 2015; Höhn 2016; 2017). One point of variation mentioned earlier are number restrictions. English APC arguments are restricted to the plural, cf. *I academic/idiot missed the deadline, while German permits them in the singular as well (24).

\section{German \\ Aber die Örtlichkeit ist für mich Bahnfahrer ideal. \\ but the location is for 1SG.ACC train.user ideal \\ 'But the location is ideal for me (as a) train user.'}

Allowing both singular and plural APCs may be crosslinguistically more common than ruling out singular APCs (Höhn 2017: Chapter 2), but ruling out plural APCs is (almost) unattested, suggesting that the plural version is the least marked. Rauh's (2004) pragmatically based explanation for the markedness difference between singular and plural APCs in German may offer a rationale for the crosslinguistic markedness of singular APCs.

\footnotetext{
${ }^{5}$ https://web.archive.org/web/20200216143946/https://www.analog-forum.de/wbboard/index. php?thread\%2F99168-stammtisch-franken\%2F = \&pageNo = 4 [accessed on 16/2/2020].
} 
However, I am not aware of any account capable of predicting whether a particular language displays a number restriction on APCs. I am going to focus on plural APCs as the least marked option here.

Another type of variation concerns the occurrence of articles in APCs. In line with the PDA, English-type APCs exclude the article. As seen in (25), Italian also behaves like English, but Spanish and Greek (along with other languages) actually require an article in APCs.

$\begin{array}{lllr}\text { noi } & (* \mathrm{i}) & \text { linguisti } & \text { Italian } \\ \text { nosotros } & *(\mathrm{los}) & \text { lingüistas } & \text { Spanish } \\ \text { emis } & *(\mathrm{i}) & \text { glosoloji } & \text { Greek } \\ \text { we } & \text { DET.PL linguists } & \\ \text { 'we students' } & & \end{array}$

Choi $(2013 ; 2014 a)$ and Höhn (2016) link the obligatory presence of the article in APCs (and the availability of pro-drop) to the unagreement phenomenon mentioned above for Spanish (13) and illustrated for Greek in (26a). The presence of the pronoun emis 'we' yields an APC, while its absence leads to an unagreement configuration with a definite R-expression subject and non-third person verbal agreement. In Italian, the unagreement configuration is ungrammatical and an APC must be used instead (26b).

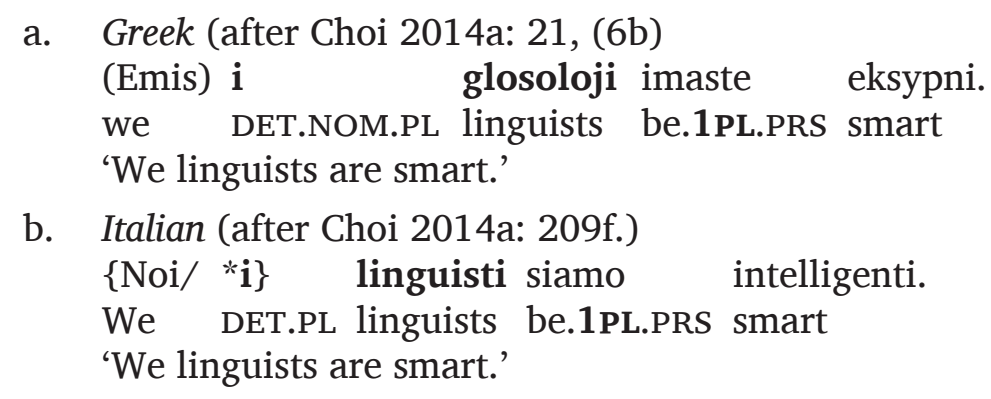

Choi (2013; 2014a; b) rejects the PDA and proposes that adnominal pronouns (and demonstratives) are base-generated in the specifier of a deixis-related head and move to Spec,DP as in (27) not only in Greek-type languages, but also in English. ${ }^{6}$ On this view, the crucial difference between English/Italian- and Greek-type languages is the overtness of D, with an overt D head required as intermediate licenser for pro-drop in an APC.

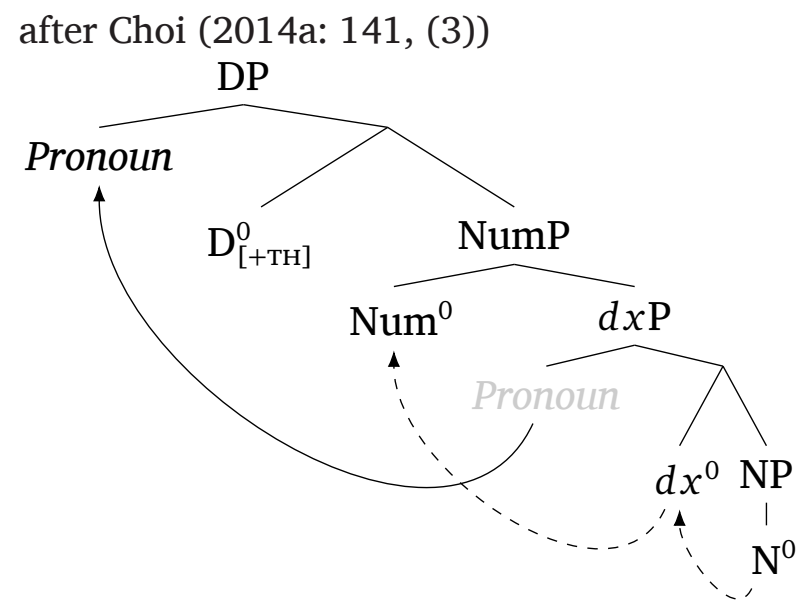

\footnotetext{
${ }^{6}$ Panagiotidis \& Marinis (2011) also locate adnominal pronouns in Spec,DP in Greek.
} 
Höhn (2016) retains the PDA for languages like English, but argues that in languages like Greek and Spanish person (and demonstrative) features are hosted on a separate head from definiteness (28). Person is encoded by the features [ \pm AUTH(or)] and [ \pm PART(icipant)] (Nevins 2007; 2011), with [+ AUTH, + PART] corresponding to the traditional first person, [-AUTH, + PART] to second and [-AUTH, -PART] to third person. Unagreement results from null-spellout of non-demonstrative ([-DEM]) Pers heads, whereas [+ DEM] Pers heads are realised as adnominal pronouns.

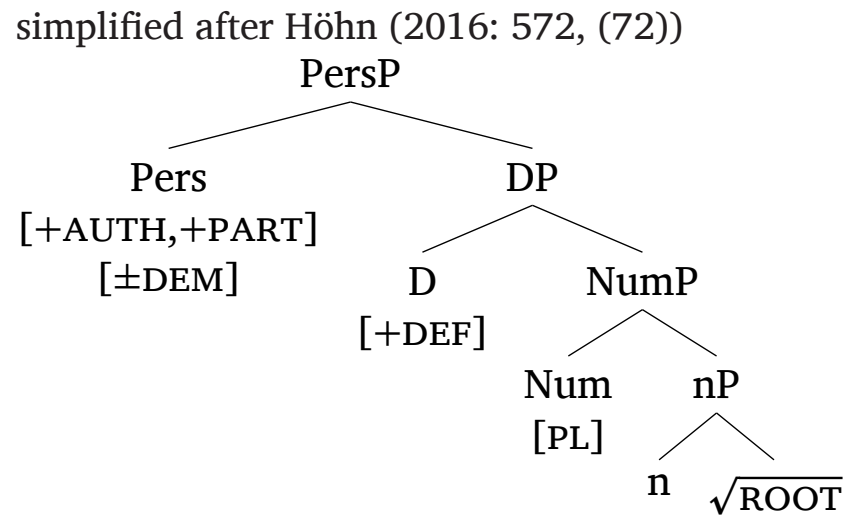

The approaches crucially differ on whether English- and Greek-type languages have uniform APC structures. Höhn, Silvestri \& Squillaci $(2016$; 2017) argue that unagreement configurations with quantified subjects support Höhn's (2016) proposal that there is a structural contrast in the location of person. Languages with "plain" unagreement typically also allow unagreeing quantified subjects (Ackema \& Neeleman 2013; 2018; Höhn 2016), see (29a), while languages without "plain" unagreement do not (29b).

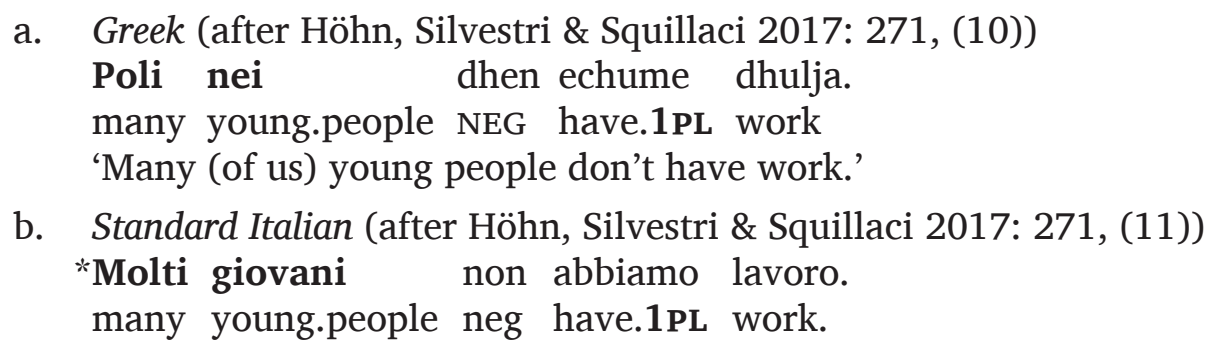

If the availability of unagreement in null subject languages was determined only by the overtness of the D head in (27), both sentences in (29) should be equally ungrammatical given the absence of a D head. The structure in (28) decouples person features from the definite article, suggesting that a (non-demonstrative, hence silent) Pers head could also occur in constructions without an (overt) article like (29a). Moreover, if the PDA holds for Italian, the ungrammaticality of (29b) results from the assumption that the quantified construction does not contain a definite D head. I conclude that Greek-type APCs differ structurally from the English/Italian type, pace Choi (2014a; b). While the PDA does not apply to Greek, this does not represent an argument against adopting it for English-type languages.

As noted above, several analyses of Japanese also reject the PDA (Furuya 2008; Noguchi 1997; Inokuma 2009). Since Japanese is strictly head-final, a pronominal determiner would be expected to occur postnominally on the PDA contrary to fact, cf. (30a). The adnominal pronoun is argued to occupy a specifier position instead as, e.g., in (30b). Importantly, even if some languages call for a specifier-based analysis of APCs, this does not raise problems for the PDA for languages like English. 


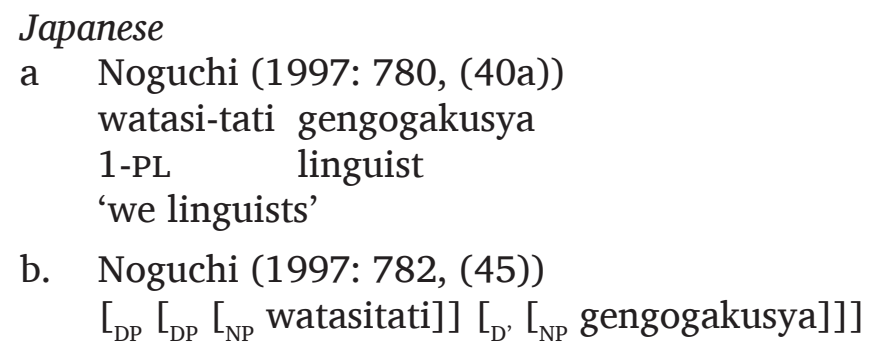

Further sources of APCs may exist. Adjunction, for instance, could be involved in languages like Imonda, reported to allow adnominal pronouns either preceding or following the noun (Seiler 1985: 61). Such a flexible distribution would be unusual for an article-like element, both typologically (Himmelmann 2001: 832) and from the perspective of a DP analysis.

\section{The third person gap}

In contrast to first and second person, third person pronouns cannot appear adnominally in English APCs (31), equally in German (32). This third person gap provides another argument for a PDA of English-type APCs.

$$
\text { we/you/*they professionals }
$$

\section{German}
a. wir/ ihr/ *sie Profis
we you.PL they professionals
b. ich/ du/ *sie/ *er Profi
I you.SG she he professional
only: 'I/you professional'

An additional aspect of the gap is the complementary distribution of third person pronouns and the article. While the article requires an overt complement (is used "transitively"), third person pronouns exclude an overt complement (are used "intransitively"), see (33) vs. (34).
a. the linguists
b. *the
a. *they linguists
b. they

\subsection{Accounting for the third person gap}

Delorme \& Dougherty (1972: 10, fn. 5) claim that neither their appositive analysis nor Postal's (1969) precursor to the PDA account for the "peculiarity of the third person forms." However, current versions of the PDA adopting the DP hypothesis can capture this pattern by assuming that adnominal pronouns and definite articles occupy the same syntactic position, leading to the hypothesis that the definite article and third person pronouns are essentially allomorphs (Postal 1969: 217; Lyons 1999: 315; Roehrs 2005; Bernstein 2008b; cf. also Sommerstein 1972, Luján 2000; 2002 and Rauh 2003). I propose a more concrete implementation below.

On the other hand, I am not aware of proposals in the literature providing an explanation for the data in (31)-(34) above based on an appositive analysis of English-style APCs. 
One might stipulate a parameterised rule against apposition to third person pronouns, but a simplistic implementation of this (strawman) approach runs into problems with the fact that apposition to third person pronouns is actually possible, cf. (35) inspired by Pesetsky (1978: 355, (17)).

(35) a. They, linguists from conviction, abhor computers.

b. *They linguists abhor a vacuum.

Example (35a) involves loose apposition, of course, so one could instead propose a restriction against close apposition to third person pronouns. The motivation for such a rule would remain mysterious, however, considering that close apposition regularly involves two expressions typically characterised as third person without problems, e.g. Bob the builder. So I suggest that difficulties with accounting for the third person gap may be added to the list of challenges for an apposition-based account of English-type APCs.

Analysing adnominal pronouns as specifiers raises similar issues, as there is no obvious reason why third person pronouns should not be able to occur in a specifier position that can host first and second person pronouns. This actually makes the right predictions if Japanese adnominal pronouns are specifiers (see Section 2.3), since Japanese has no third person gap (36). This contrast with English finds a natural explanation if English APCs are pronominal determiners, whereas it would require further elaboration if both types of languages involved the same APC structure.

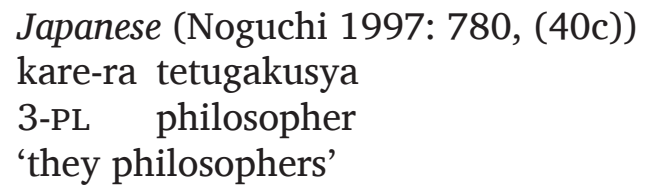

Déchaine \& Wiltschko (2002: 421f.) adopt the PDA for first and second person, but not the intuition that definite articles and third person pronouns are competing for the same syntactic position. Instead, following Cardinaletti \& Starke (1999) they propose that the lack of third person APCs in English (and presumably other languages) is due to a structural difference between first/second person pronouns, which involve a DP (37a), and third person pronouns, which only project up to a smaller $\phi \mathrm{P}(37 \mathrm{~b})$. However, it remains unclear why $\phi$ in (37b) cannot take an overt noun as complement (Asbury 2008: 141f.; see also Rauh 2003: 413 , fn. 32 for criticism), so this account does not offer a solution to the question at hand.
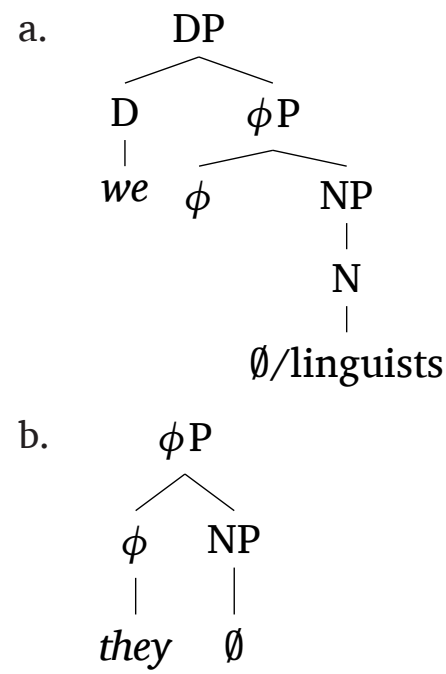
Before presenting my proposal, I want to point out the role of demonstrativity in APCs and the feature setup of D. Abney (1987: 179) suggests that third person APCs are excluded "due to demonstratives being suppletive in the paradigm." Discussing Postal's (1969) example in (38a), Sommerstein (1972) advances a similar argument, observing that the appropriate third person "counterpart" of the adnominal pronoun is a demonstrative (38b).

after Sommerstein (1972: 204, (11-13))

a. Yóu troòps will embark but the other troops will remain.

b. He said that $\{*$ they/those $\}$ troops would embark but the other troops would remain.

Lyons (1999) and Rauh (2003) propose that pronominal determiners encode not only definiteness but also demonstrative properties (see also Choi 2014a and Höhn 2016), so the string we women can be the first person counterpart of both the women and these/those women. Following them, I posit both $[ \pm \mathrm{DEF}]$ and $[ \pm \mathrm{DEM}]$ features on $\mathrm{D}$ in English-type languages. ${ }^{7}$

\subsection{Edge-sensitive allomorphy}

I now turn to my proposal of how to capture the third person gap in English. Panagiotidis (2015) argues that functional heads need to be licensed as part of an extended projection (Grimshaw 2005). A nominal phrase is an extended nominal projection ( $x n P$ ) projected by a little $\mathrm{n}$ head carrying a categorial feature $[\mathrm{N}]$, which provides an interpretive perspective to categoryless roots, enabling them to enter into syntactic structures (Acquaviva 2009; Panagiotidis 2011; 2015). Functional heads within an xnP carry an uninterpretable $[u N]$ feature that they need to check under agreement with an interpretable $[N]$ feature located on little n. Consequently, there are no intransitive determiners, since "plain" pronouns also contain an empty noun at their core (Panagiotidis 2002). This is problematic for an account of the third person gap that frames the distribution of definite articles and third person pronouns in terms of transitivity.

To account for the third person gap without a syntactic transitivity distinction between third person pronouns and articles, I propose an analysis in terms of contextually conditioned allomorphy within the non-lexicalist, realisational framework of Distributed Morphology, cf. Halle \& Marantz (1993) and much subsequent work. This means that syntax generates featurally fully specified structures without phonological content. Vocabulary Items (VIs) represent mappings from feature sets to phonological exponents and they are inserted postsyntactically by a process of Vocabulary Insertion when the structure has been shipped to the PF interface. They can be underspecified for features on the syntactic node they realise, meaning that multiple VIs may compete for insertion into the same terminal node. In this case, following the Subset Principle (Halle 1997) the most specific VI wins, i.e. the one matching the features of the syntactic node most closely. VIs may also specify restrictions on their local insertion context, which I assume to contribute to a VI's specificity according to the Subset Principle. ${ }^{8}$

I adopt Embick's (2010) $\mathbb{C}_{1}$-LIN model, particularly the view that the local domain in which the contextual restrictions for VIs are evaluated is structurally and linearly determined.

\footnotetext{
${ }^{7}$ Sommerstein reports a degradation for (38a), I suspect partly due to a collective construal of troops. Nouns that are more easily individualised, e.g. students, may work better. The intonation pattern added to (38a) by Sommerstein as well as the comments by Rauh (2003: 415f.) suggest that the demonstrative version of a pronominal determiner may be marked by stress in German and English.

${ }^{8}$ Contextual restrictions may actually be more important for determining the winning VI than the number of featural matches, see Arregi \& Nevins (2013).
} 
Hence, the triggering property has to be present inside the same spell-out domain and on a linearly adjacent node, with nodes receiving null spell-out not counting for adjacency. Spell-out domains are determined by cyclic heads (see also Bobaljik 2000; 2012; Embick \& Marantz 2008; Marantz 2009), parallel to the concept of phases (Chomsky 2001). I assume that $\mathrm{D}$ and $\mathrm{n}$ are cyclic heads, so that DP represents a spell-out domain. VIs can require in their contextual restriction to be located at the edge of a spell-out domain.

The relevant parts of an $x \mathrm{nP}$ are sketched in (39). Number and gender features are valuated under agreement with lower heads in the $x \mathrm{nP}$. For person, I employ the [ \pm AUTH(or)] and [ \pm PART(icipant)] features from Nevins (2007; 2011). A small set of relevant VIs is provided in (40). I only include the subject forms here and focus on the plural, as mentioned earlier. ${ }^{9}$

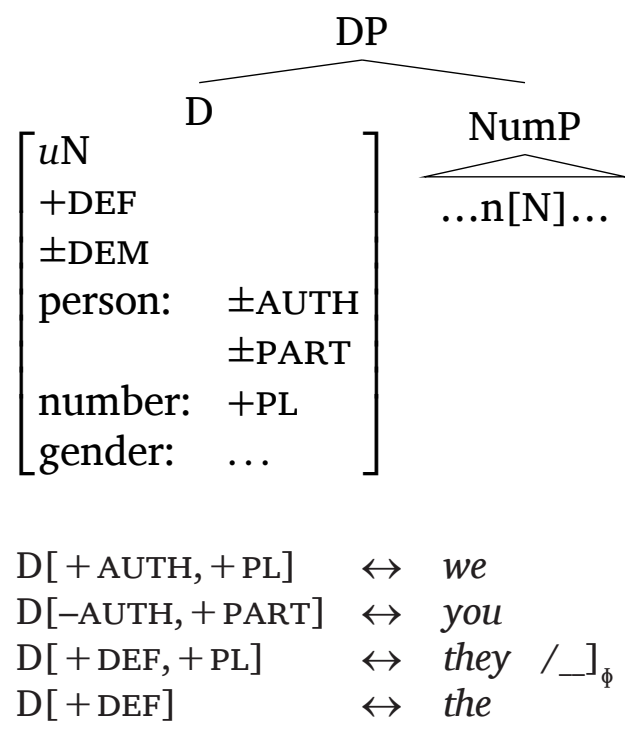

The VIs for the first and second person plural pronouns have no contextual restrictions, so they can realise a D head with appropriate feature specifications irrespective of whether or not NumP contains overt material. A plain pronoun results if there is no overt material in NumP, neither a nominalised root nor any adjectives. Overt material in NumP yields an APC.

The allomorphy between the definite article and the third person pronoun results from the interaction of the last two VIs. Even though in the implementation in (40) they and the do not include any person features, both will be able to realise D-heads specified syntactically for third person because the other VIs are all specified for [ + PART] and do therefore not compete for exponence of a [-AUTH, -PART] node. While they is more specific than the, it also has a contextual restriction requiring that it be realised at the right edge of its spell-out domain (]$\left._{\Phi}\right)$. The VI the represents the elsewhere case. When a definite D takes a phonologically empty NumP complement, there is no overt material intervening between $\mathrm{D}$ and the right edge of the spell-out domain, so the VI they wins. If any part of NumP gets an overt realisation, this intervenes between $\mathrm{D}$ and the right edge of the spell-out domain.

\footnotetext{
${ }^{9}$ In varieties allowing them linguists, them realises a demonstrative (Maček 1995; Rauh 2003: 413; Bernstein 2008a: 224; Hazen, Hamilton \& Vacovsky 2011). Examples like Tell Cooper to shift they stones there (Devonshire; Harris 1991: 23 via Radford 1993: 109) suggest that they can also realise a demonstrative in some varieties. This is no problem for the analysis, as the inventory of VIs is expected to vary between varieties.

An alternative not pursued here may be that varieties/registers allow an additional structure with the pronoun as specifier. This might account for them linguists and us linguists if specifiers are shielded from morphological case assignment in English (Parrott 2009), but *they linguists would still fall under the PDAbased account.
} 
Consequently, the contextual requirement for they is not fulfilled and the is inserted as the elsewhere case.

By underspecifying person on the VIs for they and the this implementation captures the often cited intuition that third person is a "non-person" (Benveniste 1971; Harley \& Ritter 2002; Panagiotidis 2002) while retaining the idea that third person is syntactically specified (Nevins 2007; Harbour 2016). It may, alternatively, be possible to remove the need for a $[ \pm D E F]$ feature in the spirit of the proposal that definiteness and other effects can be captured through person features (Lyons 1999; Bernstein 2008b; Longobardi 2008; Richards 2008; Bárány 2017), replacing [+DEF] by [-PART] in (40). While the choice is not central here, this alternative option raises questions concerning the semantic contribution of the [-PART] feature, since definite expressions can in principle refer to sets containing a speech act participant as illustrated in (41). ${ }^{10}$

Ackema \& Neeleman (2018: 148, (26))

a. Anyone who knows the Dutch realizes they no longer wear wooden shoes.

b. Anyone who knows the Dutch realizes we no longer wear wooden shoes.

c. Anyone who knows the Dutch realizes you no longer wear wooden shoes.

The approach sketched above carries over in principle to other languages with a pronominal determiner structure and a third person gap, but in German the so-called d-pronouns represent a potential objection (Wiltschko 1998; Elbourne 2005: 47). They are largely formally identical to the definite article, except for the genitive and the dative plural (Helbig \& Buscha 2001: 229). In contrast to the English definite article, they occur without overt complements just like personal pronouns (42), apparently conflicting with the idea that complementary distribution of articles and third person pronouns accounts for the third person gap.

$$
\begin{aligned}
& \text { German } \\
& \text { Die/ sie haben keine Ahnung. } \\
& \text { DEM.PL they have.3PL no clue } \\
& \text { 'These people/they have no clue.' }
\end{aligned}
$$

The explanation for this is that $d$-pronouns should be classified as demonstratives (Engel 1996; Diessel 1999; Helbig \& Buscha 2001; Bosch, Rozario \& Zhao 2003; Bosch, Katz \& Umbach 2007). They are associated with topic shift (Diessel 1999: 96) or avoid discourse topics (Bosch \& Umbach 2007) or the current perspectival centre (Hinterwimmer \& Bosch 2016), while personal pronouns preferably refer to continuing topics as (43) shows (see also Himmelmann 1997; Hinterwimmer 2015; Bosch \& Hinterwimmer 2016; cf. Comrie 2000 for similar Dutch data). On the most natural reading, the first sentence establishes the teachers as topic. A pronoun in the next sentence indicates continuing reference to them, while a $d$-pronoun induces topic shift, suggesting that the pupils were the ones who won.

$$
\begin{aligned}
& \text { Gestern spielten die Lehrer }{ }_{i} \text { mit den Schülern }{ }_{j} \text { eine Runde Fortnite. } \\
& \text { yesterday played.3PL the teachers with the pupils a round Fortnite } \\
& \text { Am Ende gewannen } \text { si }_{\mathrm{i}^{*}{ }_{\mathrm{j}} / \mathrm{die}_{\mathrm{j} /{ }^{*} \mathrm{i}} \text { die Partie. }} \text { in.the end won.3PL they DEM.NOM.PL the game } \\
& \text { 'Yesterday, the teachers played a game of Fortnite with the pupils. In the end, } \\
& \text { they/the latter won the game.' }
\end{aligned}
$$

\footnotetext{
${ }^{10}$ This issue resembles so-called imposter constructions like English This reporter [ = author] is not convinced that... (Collins \& Postal 2012; Collins 2014), based on which Furuya (2017) suggests a split between grammatical and notional person features.
} 
The VI sie in (44) is restricted to realising non-demonstrative D heads, while die is underspecified for demonstrativity and has no contextual requirement. This accounts for the wide distribution of the latter as exponent of articles and $d$-pronouns/demonstratives, both with and without overt complements. For reasons of space, I leave further details for future work.

$$
\begin{array}{lll}
\mathrm{D}[\text { case: } \mathrm{NOM},+\mathrm{DEF},-\mathrm{DEM},+\mathrm{PL}] & \leftrightarrow & \text { sie } /{ }]_{\phi} \\
\mathrm{D}[\text { case: } \mathrm{NOM},+\mathrm{DEF},+\mathrm{PL}] & \leftrightarrow & \text { die }
\end{array}
$$

A reviewer raises another issue for German. The honorific singular/plural pronoun of address Sie can occur adnominally (45), although it is formally identical to the third person plural pronoun (in singular and plural usage).

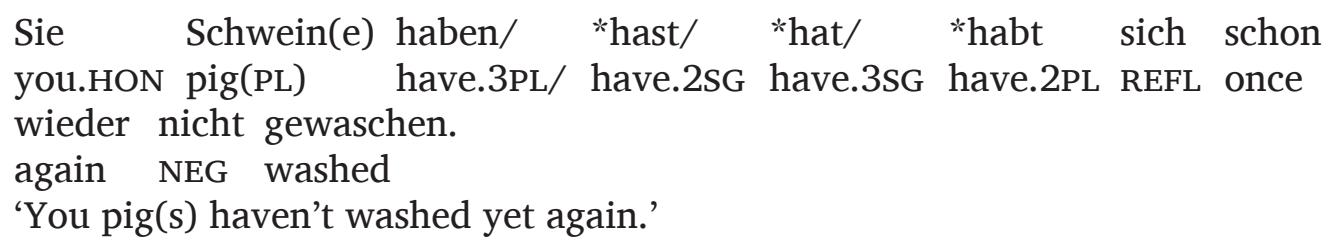

This looks like an APC with a third person pronoun, contrary to the proposed complementary distribution between "intransitive" third person pronouns and "transitive" definite articles. Simon (2007) argues that while German formal pronouns are historically derived from third person pronouns, they synchronically realise a grammatically active feature of "respect" or formality in German. This suggests that the subject in (45) is grammatically not specified for third person. Although formal pronouns are systematically syncretic with third person pronouns in standard varieties of German, they involve distinct VIs and only the one realising the third person pronoun displays the edge requirement discussed above.

The idea of distinct vocabulary items for honorifics is supported by Simon's (2007) observation that Bavarian German restricts the syncretism of third person plural and honorific pronouns to clitic subject/nominative forms, with distinct realisations in other cases, cf. Eana vs. $-s$ in (46).
Bavarian German (Simon 2007: 67, (14))
a. I versteh Eana guad, Frau Heindlmeier.
I understand 2sG.HON.ACC well, Ms Heindlmeier
'I understand you well, Ms Heindlmeier.'
b. I versteh-s guad, die neia Nachbarn.
I understand-3PL.ACC well, the new neighbours
'I understand them well, the new neighbours.'

\subsection{Further considerations and predictions}

The proposed analysis of the third person gap in languages like English and German relies on a particular syntactic configuration that encodes definiteness and person in the same position, the PDA, and competition between multiple morphological exponents of that position. This subsection discusses some consequences of the account in a crosslinguistic perspective.

On the present account, there is no conceptual or structural necessity for the third person gap. Even languages with an English-like pronominal determiner structure do not have to show the gap, as it is essentially a PF effect resulting from the competition of two distinct VIs for third person D heads. This suggests that there should be languages where 
third person pronouns and articles are not distinct and third person pronouns are freely used adnominally in a determiner position.

Palmer (2017) argues convincingly that the Oceanic language Hoava is such a case. The third person pronouns sa '3SG' and ria '3PL' can be used on their own, but also adnominally. This is illustrated for ria in (47), along with a first person APC. The adnominal pronouns are in complementary distribution with the 'general' (specific) article $n a$ and the personal articles e/eri, leading Palmer to propose a PDA as in (48).

Hoava (Palmer 2017: 426, (37b)/(38b))

a. K-eke rane la habu [ria].

NUM-one day go find.food 3PL

'One day they went to find food.'

b. Kipu mae [ria nikana Japani] de [rami nikana hupa]

NEG come 3PL man Japanese PURP 1EXCL.PL man be.black

mae $\quad$ jani $=\mathrm{i} \quad[\gamma \mathrm{ami}]$.

come kill=ACC 1EXCL.PL

'The Japanese men did not come to come and kill us black men.'

Palmer (2017: 438, (71b))

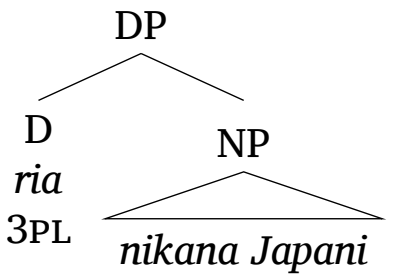

The Creole language Ndyuka may represent another example, with the same morphemes (3SG $a$ and 3PL den) being used as third person pronoun and definite article (Huttar \& Huttar 1994). See (50) for a singular example.

\section{Ndyuka (after Huttar \& Huttar 1994: 165, (738))}

[A] teke [a ondoo kulo] ne [a] gi Gazon.

3SG take 3SG hundred guilders CONJ 3SG give Gazon

'He took the hundred guilders and gave it to Gazon.'

A theoretical bias for the assumption that pronouns and articles must be distributionally distinct (see Palmer 2017 for detailed discussion of this issue for Hoava) may be one reason for why such syncretisms of articles and pronouns are sometimes analysed as homonymous markers of different categories rather than as pronominal determiners.

Many Australian languages also display third person adnominal pronouns, e.g. Kayardild (50), although there is likely variation concerning how grammaticalised these structures are (see Blake 2001; Stirling \& Baker 2007; Stirling 2008 and especially Louagie \& Verstraete 2015). Some might involve pronominal determiners, but presumably not all of them.

Kayardild (Evans 1995: 123, 239)

niya jungarra dangkaa

he big man

'the big man'

In languages like Kayardild, where "NPs lacking a determiner may be definite or indefinite" (Evans 1995: 239), third person APCs seem to "fix" a definite/familiar interpretation. 
This resembles Wiltschko's (2008) observations for plural marking in Halkomelem, where unmarked nouns are number-neutral (rather than singular as in languages like English), but addition of the (optional) plural marker enforces a plural interpretation. She proposes that number-marking in Halkomelem is an adjoined modifier rather than a functional head as in English (see also Wiltschko 2014). A hypothesis worth exploring may be that APCs in languages with this "optional" definiteness-marking also involve adjoined modifiers. Alternatively, the pronouns might also occupy a specifier position as has been proposed for Japanese (Section 2.3), which also allows third person APCs as seen in (36).

The account in Section 3.2 makes no direct predictions for the third person gap in languages that do not involve the PDA, but there seems to be no a priori reason why they should display the restriction. If they did, it should be due to different reasons than those sketched for English. So for methodological reasons I deliberately start with the strongest possible working assumption that the PDA-based account above is the only source for the third person gap. There may well be additional sources, but this working assumption presents a systematic way of identifying how far the explanation proposed for English can be extended. Below, I briefly sketch the three hypotheses in (51)-(53) that arise from this assumption.

\section{(51) Gap-article hypothesis}

If the third person gap is solely due to allomorphy between definite articles and third person pronouns, languages displaying the third person gap should generally have articles distinct from third person pronouns (recall the discussion of Hoava and Ndyuka).

\section{(52) No competition hypothesis}

Languages that allow third person APCs should either i) not have articles distinct from third person pronouns or ii) the articles they display should differ from adnominal pronouns either in their structural position or their feature makeup so as to avoid competition for insertion. For subcase ii), the clearest indication of a structural difference would be the ability of articles to occur in APCs. Potential feature mismatches could, for example, involve articles marking specificity and pronouns encoding definiteness (apart from person).

\section{(53) Gap markedness hypothesis}

If the third person gap is restricted to one type of APC structure (out of at least three, cf. Section 2.3) and dependent on a specific interaction of VIs, the availability of third person APCs should be less marked and hence crosslinguistically more common than the gap.

Before turning to an evaluation of these hypotheses against crosslinguistic data in the next section, I close this one by addressing a reviewer's concern with Icelandic Pro[NP] constructions (Sigurðsson \& Wood 2020) like (54). ${ }^{11}$ They involve a plural pronoun accompanying a nominal expression (or annex). While in many languages with this sort of inclusory construction (Lichtenberk 2000) the annex is marked, e.g. by case or an adposition, there is no special marker in Icelandic Pro[NP]s. Do these constructions bear on the question whether Icelandic has a third person gap?

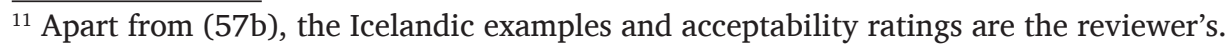



Icelandic
a. peir málfræðingur-inn
they.M linguist.SG-DEF
'he and the linguist' ('he' is not a linguist)
b. peir málfræðingar-nir
they.M linguist.PL-DEF
'he and the (other) linguists' ('he' may be a linguist)

While Pro[NP] constructions look superficially similar to APCs, their interpretation clearly differs. The annex in (54) is interpreted as denoting a proper subset of the reference set of the pronoun, while the nominal part of APCs generally does not have a distinct denotation from the adnominal pronoun. Indeed, Sigurðsson \& Wood (2020: 11-13) argue convincingly that Pro[NP] constructions are distinct from the APCs discussed here. ${ }^{12}$ Note, for instance, that the nominal part of Icelandic APCs is not marked by the definite article (55a), while the annexes of the Pro[NP]s in (54) are definite. Moreover, while the annex does not need to match the number of the pronoun in Pro[NP]s (54a), APCs are more restrictive in this respect (55b).
a. við/pið málfræðingar
we/you.PL linguist.PL
'we/you linguists'
b. *við/pið málfræðingur we/you.PL linguist.SG

The analysis of Pro[NP] proposed by Sigurðsson \& Wood (2020) establishes the connection between the pronoun and the annex through a "lock" head ", suggesting a structure like (56a). However, discussing the possible use of (preferably postnominal) demonstratives in the annex Sigurðsson \& Wood (2020: 14) suggest "that the annex may be either a full DP or a smaller category", so (56b) would be equally compatible with their model.

$$
\begin{array}{ll}
\text { a. } & \left.{ }_{\mathrm{DP}} \mathrm{D}\left[{ }_{\mathrm{nP}} "[\mathrm{NP}]\right]\right] \\
\text { b. } & \left.{ }_{\mathrm{DP}} \mathrm{D}\left[_{{ }_{\mathrm{nP}}} "[\mathrm{DP}]\right]\right]
\end{array}
$$

If the annex is a DP, it is expected to form a separate spell-out domain from the pronoun on current assumptions, so interactions of the sort discussed for English-type APCs above are excluded. Taking complete extended projections to be spell-out domains (den Dikken 2018: 55), this likely holds even if the the annex corresponds to a smaller structure, as long as it forms a distinct extended projection from the pronoun. Finally, the fact that the annex is typically marked by the definite article ${ }^{13}$ shows that in Pro[NP]s the pronoun and and the article of the annex do not compete. In conclusion, I do not think that Pro[NP]s bear on the validity of the above account for the third person gap in English-type APCs.

The question whether Icelandic APCs show a third person gap is complicated by the fact that the third person plural pronouns (peir/paer/pau 'they.M/F/N') are homonymous with a (distal) demonstrative (Einarsson 1961: 70). ${ }^{14}$ However, adnominal uses of $\mathrm{peir} / \mathrm{pcer} / \mathrm{pau}$ appear to require the noun to be modified by a relative clause. Structures like (57a) without

\footnotetext{
$\overline{12}$ While Sigurðsson \& Wood (2020: 13) seem to speculate that APCs might be structurally similar to Pro[NP]s after all, they do not elaborate and again point out differences between the constructions later on (Sigurðsson \& Wood 2020: 15).

${ }^{13}$ Sigurðsson \& Wood (2020: 9) discuss some nouns where semantic definiteness is sufficient.

${ }^{14}$ This is why Icelandic is set aside in the survey in Section 4.1.
} 
relative clause are reportedly marked, though not clearly ungrammatical. There are examples without an overt relative clause, cf. (57b), but even here the phrase reportedly retains a restrictive interpretation, possibly indicating the presence of an elided relative clause.
a. ??peir málfræðingar
they.M linguist.PL
b. pað er hörkuléleg skráning að austan í ár, okkur there is extremely-weak registration from east.DET this year, we.ACC vantar pær stelpur alveg. lack those girls completely 'The registration in the East [of Iceland] has been slow this year, those girls [who could have registered there] are missing completely [from our registry]. ${ }^{15}$

If peir málfrceðingar 'those linguists' or par stelpur 'those girls' in (57) can be considered third person APCs, Icelandic does not have a third person gap and is unproblematic for the current account. However, the lack of the definite article in APCs would raise questions concerning the no competition hypothesis (52) above and the relative clause requirement would need to be explained independently. If, on the other hand, the relative clause requirement is taken to indicate that these constructions are not actually third person APCs, Icelandic would display a third person gap. It is unclear to me which option is more plausible at this point, but I briefly speculate on the second option, as it is relevant to the current discussion.

If Icelandic has a third person gap, it could be explained similarly to the English pattern as a result of competition between the VIs of the definite article and the third person pronoun. The simplest possibility is that the suffixal article is an exponent of the D head that is lowered to the noun postsyntactically (Embick \& Noyer 2001). Alternatively, the Icelandic definite article has been argued to correspond to a lower $\mathrm{n}$ head (Julien 2005). This is equally compatible with the competition-based approach and the gap-article hypothesis (51), albeit with a twist, if Julien (2005: 57) is correct that "in Icelandic, $\mathrm{n}$ and D cannot both be spelled out." First and second person plural pronominal determiners in D would suppress realisation of the definite article in $\mathrm{n}$. The third person pronoun, however, could not be inserted as pronominal determiner due the right edge restriction described above for English, allowing the article to be overtly realised in Julien's n.

Crucially, if (57ab) do not represent third person APCs, the third person pronouns and the homonymous demonstratives peir/per/pau need to be realised by (synchronically) distinct VIs. The VIs realising the demonstrative have to lack the right edge restriction of the third person pronoun VI, since the demonstratives can occur adnominally (57b). The relative clause requirement is plausibly a semantic (or syntactic) property of this type of demonstrative. The intuition that expressions like (57a) are deviant, but not entirely ungrammatical is then due to the general availability of the demonstrative VIs peir/bcer/pau in adnominal contexts and a difficulty in identifying the (implied) relative clause required by the demonstrative. The third person pronoun VI would not play any role here.

I leave the most appropriate analysis of the Icelandic data to future research and turn to the crosslinguistic survey in the next section.

\section{Surveying the third person gap}

This section presents and discusses a crosslinguistic survey of the availability of third person APCs with reference to the hypotheses in (51)-(53).

\footnotetext{
${ }_{15}$ https://www.austurfrett.is/lifid/3842-thadh-er-hoerkuleleg-skraning-adh-austan-stelpur-oskast [accessed on 6/5/2020]. Thanks to Pórhalla Guðmundsdóttir Beck for discussion and help with the translation.
} 


\subsection{Surveyed data}

The survey reported here comprises 82 languages from 49 genera (see supplementary material). The data used are largely based on grammars and published research, in some cases on elicitation from native speakers by the author. The sample is a convenience sample insofar as it only includes languages where information on APCs was available.

The first property investigated is the availability of third person APCs (AVAILABILITY OF $\mathrm{APC}_{3}$ ), split between languages allowing third person APCs $\left(\mathrm{APC}_{3}\right)$ and those displaying a third person gap $\left(\mathrm{GAP}_{3}\right)$. The second property under investigation is the availability of articles distinct from third person pronouns (DISTINCT ARTICLE), classifying languages as having articles distinct from third person pronouns $\left(\mathrm{Art}_{\mathrm{yes}}\right.$ ) or as lacking distinct articles $\left(\mathrm{Art}_{\mathrm{no}}\right.$ ). Recall that $\mathrm{APC}_{3}$ languages where third person pronouns and definite articles are non-distinct (like Hoava) are in line with the PDA and in fact represent the most straightforward type of pronominal determiner. These languages are therefore classified as Art ${ }_{\text {no }}$ here to avoid interfering with the investigation of the gap-article hypothesis (51), i.e. whether $\mathrm{GAP}_{3}$ implies the presence of an article.

A similar issue arises for the distinctness of demonstratives (DISTINCT DEM). In some languages they are used as third person pronouns (Dem $=3 \mathrm{rd}$ ), while other languages have distinct third person pronouns (Dem $\neq 3 \mathrm{rd}$ ). Since demonstratives are typically able to occur attributively as nominal modifiers, in Dem $=3$ rd languages any tentative third person APCs are formally identical to plain demonstrative-noun constructions. Consequently, it is unclear whether an apparent third person APC in such a language involves an adnominal pronoun or an attributive demonstrative. While attributive demonstratives in some of these languages might indeed be analysed as (a type of) third person APCs, I set them aside here in order to focus on the role of definite articles, but list them in (58) for reference. ${ }^{16}$

Languages where Dem $=$ 3rd

Art $_{\text {yes }}$ : Lavukaleve, Danish, Icelandic, Norwegian, Swedish, Calabrian Greek, Standard Modern Greek, Supyire

Art $_{\text {no }}$ Turkish, Mangarayi, Bilua, Inuktitut, Kashmiri, Marathi, Punjabi, Persian, Lezgian

\subsection{Results}

Table 1 shows the distribution of the surveyed languages for the two main factors DISTINCT ARTICLE and AVAILABILITY OF $\mathrm{APC}_{3}$ as well as DISTINCT DEM. Excluding the Dem $=3 \mathrm{rd}$ column leaves a total of 65 languages from 40 genera. For these, Figure 1 visualises the absolute and relative frequency of Art yes languages as a dependent of $\mathbf{A P C}_{3}$.

Table 1: Contingency table.

\begin{tabular}{|l|r|r|r|r|}
\hline & \multicolumn{2}{|c|}{ APC $_{\mathbf{3}}$} & \multicolumn{1}{|c|}{$\mathbf{G A P}_{\mathbf{3}}$} & Total \\
\cline { 1 - 5 } & Dem $\neq$ 3rd & Dem = 3rd & Dem $\neq$ 3rd & \\
\hline Art $_{\text {yes }}$ & 14 & 8 & 14 & 36 \\
\hline Art $_{\text {no }}$ & 35 & 9 & 2 & 46 \\
\hline Total & 49 & 17 & 16 & 82 \\
\hline
\end{tabular}

\footnotetext{
${ }^{16}$ The issue of adnominal demonstratives and third person pronouns in Scandinavian is complex and I refrain from addressing it here. Cf. Johannessen (2008) and Julien (2005) for discussion of prenominal determiners, pronominal psychological demonstratives and their interaction with definiteness marking across Scandinavian; see also Section 3.3.
} 
Considerably more languages in the sample display $\mathbf{A P C}_{3}$ than $\mathbf{G A P}_{3}$, as expected on the gap markedness hypothesis (53). Among the $\mathbf{G A P}_{3}$ languages, the majority have a distinct article in line with the gap-article hypothesis (51). Also, most Art $_{\mathrm{no}}$ languages allow third person APCs, in line with the no competition hypothesis (52). The applicability of the hypotheses will be discussed in more detail in Section 4.3. However, since the sample is not balanced, the overrepresentation of language families (particularly Indo-European ones) might influence the data.

In order to counteract this, I take into account LANGUAGE GENUS (Dryer 1989) as an additional factor. Table 2 provides a count of distinct genera for each cell. Note that the totals do not exactly add up, since languages of the same genus may be represented in more than one cell. The general tendencies of the raw data in Table 1 remain intact, but the relative rarity of the third person gap becomes even clearer here with 35 genera allowing third person APCs and the third person gap instantiated in merely 6 genera.

To further test whether there is a stable effect of the availability of third person APCs on the availability of articles (gap article hypothesis) in the present sample, a statistical analysis was conducted using R 4.0.0 (R Core Team 2020) with the IDE RStudio 1.2.5042 (Rstudio Team 2020), with DISTINCT ARTICLE modelled as dependent variable and AVAILABILITY OF $\mathrm{APC}_{3}$ as predictor in a generalised linear mixed-effects model using the lme4 package (Bates et al. 2015). In order to alleviate the impact of overrepresented genera, LANGUAGE GENUS was modelled as random effect. The resulting model has a positive intercept of 1.35 ( $S E=0.69$ ), reflecting the fact that the sample contains slightly more $_{\text {Art }_{n o}}$ languages, and a negative fixed effect of -3.75 (SE = 1.65) for AVAILABILITY OF $\mathbf{A P C}_{3}$, indicating that $\mathbf{G A P}_{3}$ languages are likely to have a distinct article. Following the suggestion by Bates et al. (2015: 33f.), the statistical inference from the generalised mixed-effects model was estimated by means of a log-likelihood test comparing the model including the factor AVAILABILITY OF $\mathrm{APC}_{3}$ as a fixed effect (Bayesian information

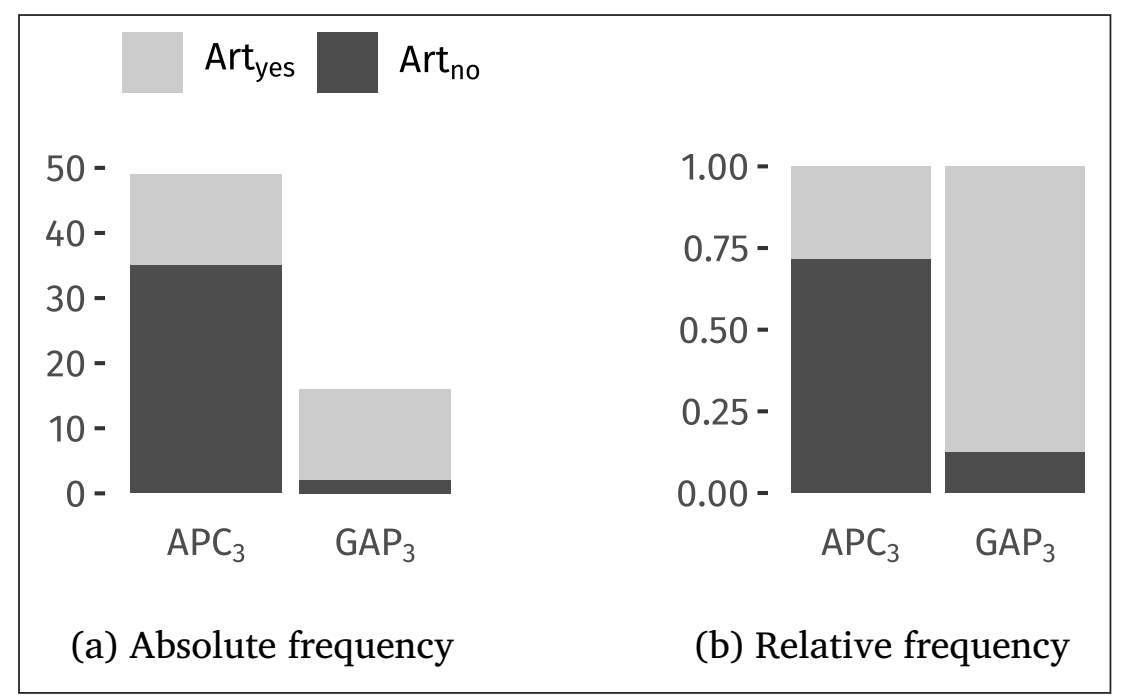

Figure 1: Availability of distinct article by availability of third person APCs.

Table 2: Distribution compressed by LANGUAGE GENUS.

\begin{tabular}{|l|r|r|r|}
\hline & APC $_{\mathbf{3}}$ & GAP $_{\mathbf{3}}$ & Total \\
\hline Art $_{\text {yes }}$ & 11 & 6 & 16 \\
\hline Art $_{\text {no }}$ & 28 & 1 & 29 \\
\hline Total & 35 & 6 & 40 \\
\hline
\end{tabular}


criterion (BIC) $=81.69$ ) to a model without fixed effects (BIC $=90.33$ ). The difference between model deviances suggests that the fixed effect of AVAILABILITY $\mathrm{OF} \mathrm{APC}_{3}$ cannot be dropped without a significant loss of information, as the log-likelihood test results in a $\chi^{2}$ value (difference between model deviances) corresponding to a significant p-value $\left(\chi^{2}=12.82, p<0.01\right)$. The outcome of the model comparison is therefore consistent with the gap-article hypothesis (51) that the availability of third person APCs is a relevant predictor for the presence of a distinct article.

Figure 2 maps the Dem $\neq$ 3rd languages according to their status for AVAILABILITY OF $\mathrm{APC}_{3}$ and DISTINCT ARTICLE. For better readability due to the high density of languages, languages of Papua-New Guinea and the Timor-Alor-Pantar area are mapped separately in Figure $3 .{ }^{17}$ The illustrated distribution raises the possibility that the third person gap may

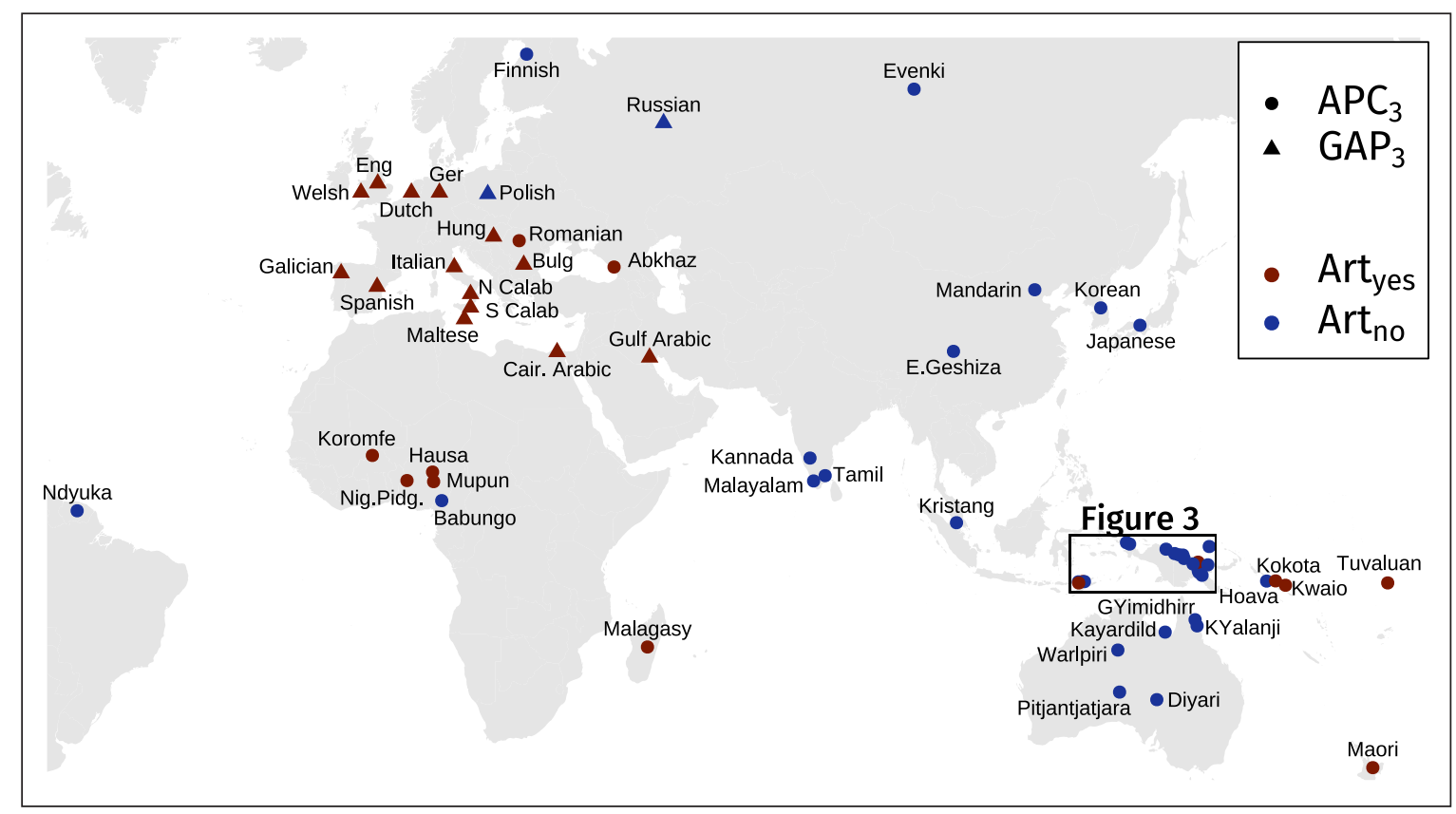

Figure 2: Geographical distribution of availability of distinct articles and third person APCs.

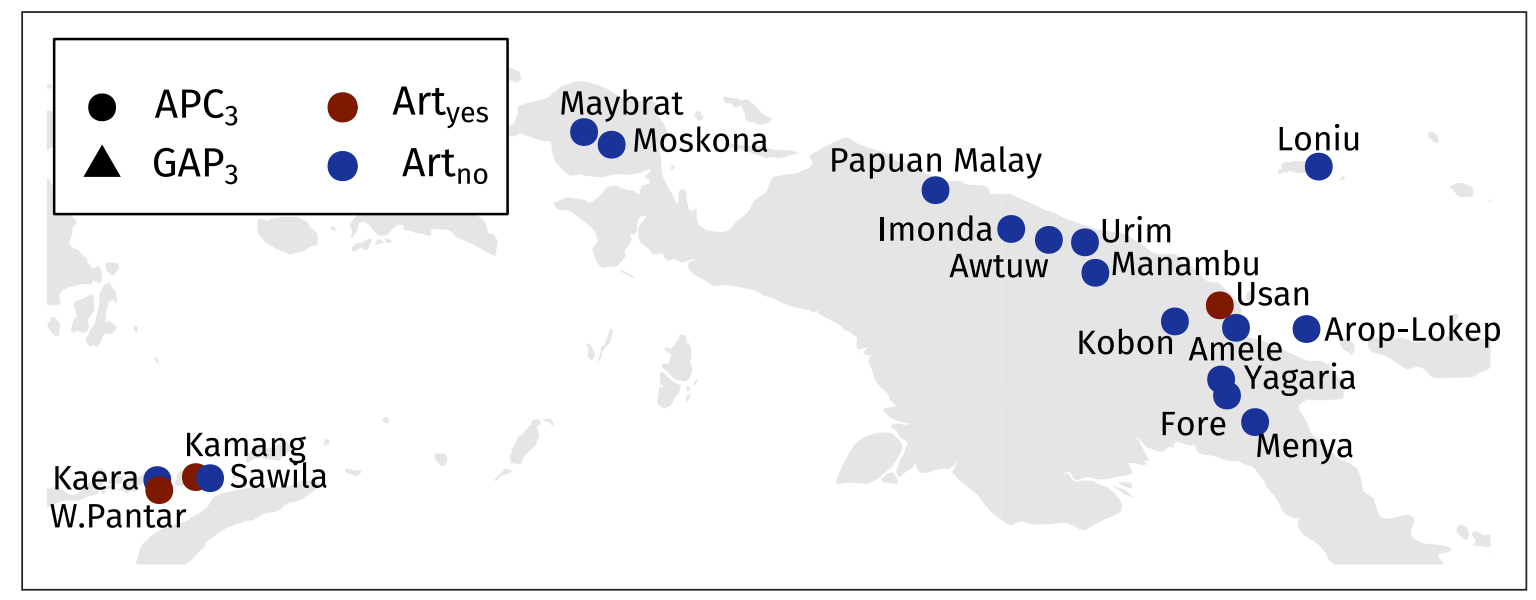

Figure 3: Distribution of availability of distinct articles and third person APCs, close-up of Papua-New Guinea and vicinity.

\footnotetext{
${ }_{17}$ Maps were produced using the R packages ggplot2 (Wickham 2016), mapdata (Becker, Wilks \& Brownrigg 2016) and scico (Pedersen \& Crameri 2018). Language coordinates are generally based on glottolog 4.2.1 (Hammarström et al. 2020). German uses the WALS coordinates (Dryer \& Haspelmath 2013), northern Calabrese those of Verbicaro/Italy and southern Calabrese those of Bova Marina/Italy.
} 
represent an areal feature. All languages displaying the third person gap in the present sample cluster in Europe and nearby, in an area that could be characterised as Standard Average European (Haspelmath 2001) plus Welsh and Semitic. The two counterexamples to the gap-article hypothesis appear to be spoken in the eastern periphery of this tentative area.

\subsection{Discussion}

The results above are largely in line with the three hypotheses from Section 3.3, as far as the overall patterns are concerned. The third person gap is clearly not universal and in fact seems to be considerably less common than the availability of third person APCs as stipulated by the gap markedness hypothesis (53). Most languages in the sample that lack distinct articles allow third person APCs, which is a corollary of the gap-article hypothesis (51) and the no competition hypothesis (52). Finally, the availability of third person APCs seems to be a relevant predictor for the availability of distinct articles, as suggested by the gap-article hypothesis. In this section, I discuss the languages making up each of the four possible combinations of AVAILABILITY OF $\mathrm{APC}_{3}$ and DISTINCT ARTICLE, address some challenges for the current proposal and consider the significance of the data for the status of the PDA and other analyses.

\subsubsection{Languages allowing third person APCs}

I begin by addressing the no competition hypothesis (52), the hypothesis that languages with third person APCs should tend to either lack distinct articles or be able to also use articles in APCs. The languages relevant for the first disjunct are listed in (59).

(59) $\quad \mathbf{A P C}_{3}$ and $\mathbf{A r t}_{\mathrm{no}}$ : Japanese, Korean, Evenki, Mandarin, East Geshiza, Kayardild, Diyari, Warlpiri, Pitjantjatjara, Guugu Yimidhirr, Kuku-Yalanji, Imonda, Manambu, Awtuw, Fore, Yagaria, Amele, Kobon, Maybrat, Menya, Moskona, Urim, Sawila, Kaera, Hoava, Papuan Malay, Arop-Lokep, Loniu, Ndyuka, Finnish, Kristang, Tamil, Kannada, Malayalam, Babungo

This group contains several languages discussed in Section 3.3, namely those proposed to involve regularised third person determiners in a PDA, Hoava and Ndyuka, and those potentially involving specifier- or adjunction-based APC structures, specifically Japanese, Kayardild and other Australian languages. The availability of third person APCs is the default situation for languages without distinct articles on the view developed here and in principle compatible with various types of APC structures. I am not going to address the structure of all languages in (59) here, but I briefly comment on the inclusion of Finnish, since Sulkala \& Karjalainen (1992: 277f.) seem to imply that Finnish has a third person gap. In spite of the lack of an overt definite article, Asbury (2008: Chapter 3) and Gröndahl (2015a; b) argue that Finnish actually projects a DP. Gröndahl proposes that the neutral demonstrative $s e$ is developing into a definite article, cf. (60).

$$
\begin{aligned}
& \text { Finnish (Sulkala Karjalainen 1992: 269, (1308)) } \\
& \text { Näin tytön. Se tyttö itki. } \\
& \text { see-IPFV-1SG girl-ACC it girl cry-IPFV-3SG } \\
& \text { 'I saw a girl. That girl was crying.' }
\end{aligned}
$$

If Finnish is head-final in the nominal domain (Asbury 2008), this prenominal determiner is likely in a specifier position, as independently argued by Gröndahl. This contradicts a plain PDA of Finnish APCs, suggesting that adnominal pronouns are also located in a 
(possibly the same) specifier position. On the current perspective, this leads to the default expectation that third person APCs should be available, contrary to Sulkala \& Karjalainen's (1992) implication. This prediction actually appears to be borne out, as suggested by data like (61), which is why I classify the language as $\mathbf{A P C}_{3}{ }^{18}$

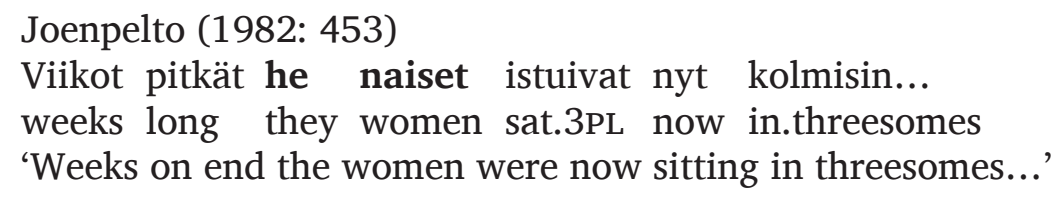

The second disjunct of the no competition hypothesis suggests that one option for $\mathbf{A P C}_{3}$ languages to have distinct articles is if they are not subject to the PDA and articles and adnominal pronouns occupy different syntactic positions. This would prevent their exponents from competing for insertion into the same node, leading to the expectation that articles should be able to occur in APCs. This can indeed be observed for a large number of the languages of this type, which are listed in (62).

$\mathbf{A P C}_{3}$ and Art ${ }_{\text {yes }}$ : Usan, Kamang, Western Pantar, Hausa, Mupun, Malagasy, Kokota, Kwaio, Maori, Tuvaluan, Nigerian Pidgin, Koromfe, Abkhaz, Romanian

I have no relevant data for Kamang and Usan, but articles occur in APCs in Abkhaz (Hewitt 1989: 159), Romanian (Cornilescu \& Nicolae 2014: 20; pace Mallinson 1986: 258) and Western Pantar (Holton 2014: 74f.). The same holds for APCs in the Oceanic languages Tuvaluan (Besnier 2000: 393), Maori (63a) and Kokota (63b). Matters are less clear for Kwaio (63c), where the few reported examples do not contain an article, but an unidentified marker - $a$ between pronoun and noun. This is where the article occurs in APCs in the other languages, so it might be a reduced form of the specific plural article nga. Moreover, at least in Kokota the article does not seem to be mandatory in APCs (64), so something similar could hold in Kwaio.

a. $\quad$ Maori (Bauer 1993: 373, (1673))

E kaha rawa atu [maatou ngaa kaiako naa] ki te pata.patai TAM strong very away 1PL.EXCL the.PL teacher DEM.2 to the RED·ask 'We teachers ask a lot of questions.'

b. Kokota (after Palmer 2008: 123, (4.1b))

ka gai ira nakoni zuzufra...

LOC we.INCL the.PL person black

'With us black people...'

c. Kwaio (after Keesing 1985: 104)

'a-gauru-a ta'a i 'Ai'eda

FOC-3PL-? people LOC 'Ai'eda

'those 'Ai'eda people'

(64) Kokota (Palmer 2008: 95, (3.70a))

gai nakoni zuzufra

we.EXCL person black

'we black people'

\footnotetext{
${ }^{18}$ Thanks to Anders Holmberg and Tiina Savolainen for discussion and help with glossing.
} 
In any case, articles in these Oceanic languages seem to mark something other than definiteness (Keesing 1985: 86; Bauer 1993: 350-355; Besnier 2000: 367; Palmer 2008: 80), so their feature setup may be sufficiently distinct from that of third person pronouns to avoid competition in line with the no competition hypothesis (52ii).

In Hausa, APCs can optionally occur with the morpheme described as definite article, actually a "previous reference marker" (Newman 2000: 143) marking noun phrases mentioned before in the discourse. This predicts that the marker should not appear in discourse-initial APCs, but also explains why the marker is not in complementary distribution with adnominal pronouns, as they encode different features. Similar considerations apply to related Mupun, where the article is also a "previous mention marker" (Frajzyngier 1993: 169f.) and can occur in APCs (Frajzyngier 1993: 93f.).

Koromfe APCs also contains a prenominal "article" (Rennison 1997: 251), which is, however, not related to definiteness marking (Rennison 1997: 80f.) and therefore not expected to interfere with the expression of third person APCs even on the PDA. However, phrase-final demonstrative/definiteness markers can also occur in APCs (John Rennison p.c.), suggesting that their structure is not subject to the PDA in this language.

In Nigerian Pidgin, the definite article seems to be optional (Faraclas 1996: 172), but in contrast to other languages with "optional articles" discussed above, the article is ruled out in APCs (Niclas Faraclas p.c.). This is suggestive of a PDA for the language. The definite article dì is distinct from the third person pronouns (im 3SG/dem 3PL), which can occur adnominally though (dem ticha 'they teachers', Niclas Faraclas p.c.). The present approach leads me to expect a featural difference between the article and the third person pronoun due to the no competition hypothesis (52). Since Nigerian Pidgin is an Englishbased creole, note the similarity to English them linguists, see fn. 9, which may suggest that dem is another demonstrative form in addition to dis 'this' and dat 'that'.

Malagasy raises similar issues as Nigerian Pidgin and I would expect some featural distinction between articled noun phrases and third person APCs. I do not attempt an explanation here, but see Paul \& Travis (to appear) for some relevant data.

\subsubsection{Unexpected third person gaps}

The languages in (65) are all in line with the basic prediction of the gap-article hypothesis (51) that languages with the third person gap should have distinct articles.

GAP $_{3}$ and Art $_{\text {yes }}$ : Dutch, English, German, Italian, northern Calabrian, southern Calabrian, Welsh, Hungarian, Galician, Spanish, Bulgarian, Cairene Egyptian Colloquial Arabic, Gulf Arabic, Maltese

Dutch, English, German, Italian, Welsh, Hungarian and northern and southern Calabrian behave as expected under the PDA also beyond the lack of third person APCs, as they also rule out definite articles in APCs. Matters are more complicated in Bulgarian, Galician, Spanish and the three Semitic languages. In these languages, the definite article is not in complementary distribution with the pronoun in APCs. In Section 2.3, unagreement in Spanish was connected to the inapplicability of the PDA. Galician and Bulgarian also allow unagreement (Höhn 2016) and plausibly work similarly. However, the Semitic languages also require articles in APCs (66), but lack unagreement (Höhn 2016: 560, fn. 15).

a. $\quad$ Cairene Egyptian Arabic (Gary \& Gamal-Eldin 1982: 80, (533))

Pintu Rit-talamza tifibbu Rillisb.

you.PL DET-students 2PL.like playing

'You students like playing.' 
b. Maltese (Borg \& Azzopardi-Alexander 1997: 202, (915))

Intom il-haddiema ghandkom tinghaqdu.

you.PL DET-workers have-2PL unite-2PL

'You workmen should unite together.'

Following the discussion in Section 2.3, the lack of unagreement suggests that the Semitic APCs structure should actually involve pronominal determiners, in contrast to Bulgarian, Galician and Spanish. The unexpected lack of complementary distribution of definite article and adnominal pronouns can be explained if articles in these languages are a morphological reflex of definiteness features that are syntactically represented elsewhere in the nominal structure, potentially on D. This has effectively been proposed independently for definiteness spreading or polydefiniteness in these languages, where the definite affixal articles do not only mark the noun, but also any adjective modifying a definite noun phrase. Against this background, definiteness has been argued to be part of the set of $\phi$-features at least in Arabic and Hebrew (Fassi-Fehri 1999; Danon 2001; Shlonsky 2004; Pereltsvaig 2006; Danon 2008). I assume that Maltese works comparably.

Effects of this sort have been analysed in Distributed Morphology as post-syntactic insertion of dissociated morphemes (Embick 1997; Harley \& Noyer 1999; Embick \& Noyer 2001) which "reflect certain syntactic properties (or configurations) but do not in any sense contribute these properties to syntax" (Embick \& Noyer 2001: 558). A uniform analysis of adjectival and nominal definiteness marking in these languages could treat all articles as dissociated morphemes marking agreement with an abstract [ + DEF] feature in D. ${ }^{19}$ The structure of an APC after insertion of the dissociated morpheme could then look like (67), abstracting away from possible roll-up movement (Shlonsky 2004; Pereltsvaig 2006). For illustration, I assume that the dissociated [ + DEF] morpheme on nouns adjoins to n, following Embick \& Noyer's $(2001,583)$ proposal for the Swedish definite suffix. Alternatively, it may be adjoined to Num if nouns raise to Num in the relevant languages.

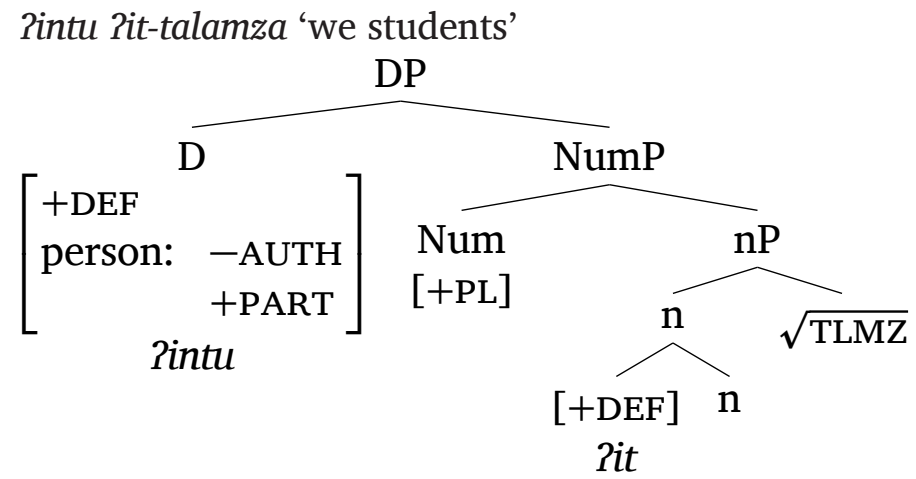

If this is on the right track, the Semitic languages only superficially contradict the gaparticle hypothesis. They encode definiteness and person features on the same head as expected on the PDA and the third person gap can be explained essentially as in English. The main difference would be that the relevant allomorph blocking insertion of the third person pronoun is not the definite article, but a null morpheme realising a definite $\mathrm{D}$ head specified for [-PART], i.e. third person.

This approach does not transfer to unagreement languages like Bulgarian, Galician and Spanish with a structure like (68), see Section 2.3.

\footnotetext{
${ }^{19}$ For a similar intuition compare Corbett's $(2006,135)$ treatment of definiteness "as a feature value being imposed on the noun phrase as a whole, which may be indicated at more than one point in the phrase." See also Danon (2010: 145, fn. 1).
} 


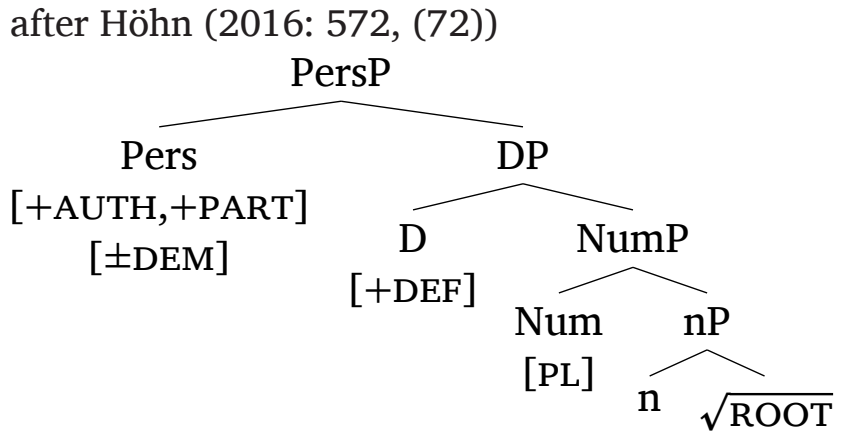

In some languages with unagreement, like the two Greek varieties in (58) above, demonstratives and third person pronouns are non-distinct, so the third person gap is no issue. This is easily captured in (68) through the association of the Pers head with demonstrative features (see also Choi 2014a). Adnominal demonstratives realise third person APCs in these languages, while the Pers head in non-demonstrative structures with third person features simply receives null spell-out, yielding a plain definite DP.

This cannot be the whole story for languages with dedicated third person pronouns like Bulgarian, Galician and Spanish. Considering that they do not involve a pronominal determiner structure and still disallow third person APCs, they represent a genuine counterexample to the working assumption from Section 3.3 that the English-type interaction between definite article and third person pronoun is the only way of yielding a third person gap. Note that this is not an argument against the PDA- and PF-based analysis of the third person gap proposed here for English, but simply suggests that a third person gap may also arise in different configurations. It is also not a reason to adopt an alternative analysis of unagreement over that based on the structure in (68), since neither Choi's (2014a) specifier-based proposal nor the view that APCs in these (and other) languages involve apposition (Ackema \& Neeleman 2018) offer an obvious explanation for the third person gap in these languages.

I am not offering a worked-out solution to this problem here, but a brief sketch of a possible analytical approach based on (68) and the assumption that the third person gap is an edge-based PF phenomenon even here. The account for (68) encodes the difference between overt and covert pronouns through the $[ \pm \mathrm{DEM}]$ feature. This is probably sufficient for languages that use demonstratives as third person pronouns (e.g. Greek), but in languages like Spanish demonstratives and third person pronouns can both appear "pronominally." This suggests that they differ in some respect, even though generally pronouns and demonstratives seem to behave as members of the same distributional class (Blake 2001; Choi 2014a; Höhn 2016). So there has to be an additional feature that distinguishes whether Pers is realised as a demonstrative or a personal pronoun. If the VIs for demonstratives are underspecified for this distinguishing feature and the VI for the third person pronouns is restricted to right-edge contexts, then the VI for the third person pronoun can be inserted in right-edge contexts on a Pers node containing the relevant feature. It could not be inserted in structures where Pers contains the relevant "pronoun feature" but is accompanied by further overt material within the nominal phrase. The demonstrative VI would always win instead, creating the observable third person gap. A proper investigation would have to check in detail whether such an approach makes the right predictions, and an important open question concerns, of course, the identity and representation of the hypothetical distinguishing feature.

It may be noted that even though the three languages above do not fall under the PDAbased explanation for the English third person gap, they still conform to the hypothesis 
that $\mathbf{G A P}_{3}$ languages generally have distinct articles. Recall that all these languages are found in the same overall area, roughly corresponding to Standard Average European plus Welsh and Semitic. If the third person gap is indeed restricted to this geographically relatively contiguous area, this raises the possibility that it is connected to areal diffusion of a surface pattern, although its specific implementation may vary depending on particular aspects of nominal structure. The fact that the wide occurrence of article systems is also considered a feature of Standard Average European (Haspelmath 2001: 1494) would be compatible with a scenario where the development of both features is indeed connected.

\subsubsection{Unexpected lack of article}

The languages contradicting the gap-article hypothesis (51) by displaying a third person gap but no articles are listed in (69).

$$
\text { GAP }_{3} \text { and } \text { Art }_{\mathrm{no}}: \text { Russian, Polish }
$$

There is much debate about whether or not Slavic articleless languages involve a DP structure, see Pereltsvaig (2013) for an overview. However, the authors making specific reference to APCs (Willim 2000; Rutkowski 2002) in this debate suggest that pronouns are base-generated in $\mathrm{N}$ and that APCs should be analysed as appositions. As mentioned in Section 3.1, though, it is not clear how the third person gap would be addressed in an appositive analysis.

I suggest that a PDA-based analysis applies to these languages after all, although they lack any overt articles. This picks up a suggestion by Bošković (2008: fn. 9) and Bošković (2015) that pronouns may be the only Ds in this class of languages. The approach to APCs sketched below does not depend on Bošković's (2008) general proposal that bare noun phrases in Slavic do not involve a silent D.

The account I suggest parallels that for the Semitic languages above, with the difference that Slavic languages lack definiteness concord. So APCs have a D position at least for pronominal determiners and third person adnominal pronouns are ruled out because the VIs for third person pronouns have a contextual requirement to be at the right edge of their spell-out domain. The identification of the third person gap as a feature of Standard Average European raises the possibility that this pattern, i.e. a distributionally restricted third person pronoun, entered these languages through grammatical replication (Heine \& Kuteva 2005) due to language contact. Note that Old Church Slavonic did not display a third person gap, since it lacked independent third person pronouns and used demonstratives instead (Gardiner 1984: 42f.), aligning it with category (58) above. The details of the derivation of the third person gap depend on whether Russian and Polish are assumed to have a null DP structure. I present both options below.

If bare nouns (can) involve DP structure, there is a null elsewhere VI for the D head, which is inserted in a [-PART] D head if there is no more specific candidate. The example VIs in (70) are for Russian. If there is no overt material between D and the right edge of the DP, the contextual condition of the third person pronoun VI in (70) is met and the result is the third person pronoun. If there is overt material, the third person pronoun VI cannot be inserted and the zero morpheme is inserted as a default, yielding a bare noun phrase.

$$
\begin{array}{lll}
\mathrm{D}[\text { case: NOM, -PART, -DEM, +PL] } & \leftrightarrow \text { oni /_] } \\
\mathrm{D}[-\mathrm{PART}] & \leftrightarrow & \emptyset
\end{array}
$$

If pronouns are really the only D elements in these languages, as suggested by Bošković, then the second VI in (70) does not exist. In a DP structure involving a [-PART] D head 
alongside other material, there would then be no appropriate VI for the realisation of D. To stay consistent with Bošković's (2008) claim that bare noun phrases do not include DP structure, one would have to assume in this case that missing VIs do not simply lead to null-spell-out, but to an infelicitous derivation. This is in line with the suggestion by Panagiotidis (2015: 70-72) that missing VIs limit the productivity of word formation.

The next section discusses why I take a PDA-type structure to provide a better basis than appositive or specifier-based approaches for making adequate predictions in a PF-based approach to the third person gap.

\section{Discussion of other approaches}

Keeping in mind the limitations of the survey, I take it to support the claim that there is a relationship between the third person gap and the existence of definite articles, largely as expected on the PDA- and PF-based account proposed in Section 3.2 for English-type languages. Section 4.3.2 has shown that there appears to be at least one other structure beyond the PDA that can also give rise to the third person gap, namely in languages with unagreement and distinct third person pronouns. While I can currently offer no full analysis for the third person gap in those languages, it is noteworthy that the relevant structure has been argued to be essentially an extension of the DP structure underlying the PDA. The hypothesis that the third person gap is essentially a PF phenomenon that applies only in some of the crosslinguistically attested APC types is in line with its relative crosslinguistic rarity and the areal nature of its distribution.

In the remainder of this section, I summarise some issues that I think the third person gap raises for alternative approaches to English-type APCs. In particular, I address a lexicalist version of the PDA that dispenses with the realisational aspect of my account, appositive approaches and analyses locating adnominal pronouns in specifier positions. I conclude with some comments on potential NP analyses of the third person gap.

A lexicalist version of the PDA (Abney 1987) would likely take we linguists to be wellformed because we can be transitive and *they linguists to be bad because they is obligatorily intransitive. Setting aside conceptual reasons against assuming intransitive functional heads (Panagiotidis 2002; 2015), such an approach would also not capture the relation of the third person gap to the competition with the definite article in a transparent way.

As discussed earlier, this issue arises even more urgently for appositive accounts of English-type APCs, where the relationship between article and noun in a definite noun phrase is taken to be fundamentally different from that between pronoun and noun in an APC. This means that a hypothetical account proposing a (parametrised) restriction against close apposition to a third person pronoun would offer no obvious reason why a language with such a restriction should also tend to have definite articles. Such an approach would also beg the question of why the restriction applies to third person pronouns, but not to other third person expressions.

Similar issues arise for specifier-based accounts for English APCs (e.g. Choi 2014a) assuming that the adnominal pronoun is in a phrasal position distinct from the definite article, namely Spec,DP instead of D. While an agreement relation between the adnominal pronoun and $\mathrm{D}$ might seem to provide an alternative possibility of excluding a third person element, it is not clear why this mechanism would allow demonstratives in the same position. The proposal that third person pronouns are (often) deficient, whereas first and second person pronouns are structurally larger strong forms (Cardinaletti \& Starke 1999) might provide a handle on the issue if deficient forms are assumed to be excluded in the relevant specifier positions for some reason. However, Cardinaletti \& Starke (1999: 43, fn. 1) also suggest that English third person plural pronouns may not be deficient, but have demonstrative properties due to the initial th- morpheme (cf. also Bernstein 2008a). 
If anything, this leads to the expectation that they should be able to occur in the same specifier position as demonstratives (and the licit adnominal pronouns). I conclude that this approach does not provide a fully coherent account for the English third person gap at the core of this paper.

One factor motivating specifier-based accounts appears to be the possibility of a unified treatment of APCs with (Greek, Spanish) and without articles (English, German, Italian). As discussed in Section 2.3 though, assuming structural uniformity might actually make the wrong predictions for quantifier unagreement in null subject languages.

One may consider the possibility of applying the PF-based aspect of the account in Section 3.2, i.e. some form of right-edge sensitivity for VIs, to an appositive or specifierbased structural analysis of APCs. For an appositive account like (71a), this option seems unlikely given that apposition is normally taken to involve a relationship between two complete nominal expressions. It would seem undesirable to allow Vocabulary Insertion to be sensitive to material beyond the edges of an extended projection.

$$
\begin{array}{llr}
\text { a. }\left[\left[_{\text {PronP }} \text { Pron }\right]\left[{ }_{\mathrm{XP}} \text { nominal part }\right]\right] & \text { apposition } \\
\text { b. } \quad\left[\mathrm{XP} \text { PronP }\left[{ }_{\mathrm{X}}, \mathrm{X} \ldots \text { nominal part }\right]\right] & \text { specifier }
\end{array}
$$

For a specifier-based account like (71b), the issues arising are slightly more intricate. As specifiers, pronouns and demonstratives are phrasal, but do not contain a nominal core (contra Panagiotidis 2002). This may suggest that they do not form an independent extended projection, allowing them to be considered part of the same extended projection as the head they form a specifier of, including the remaining material in its complement. However, when PronP or DemP are used independently as "pronominal" arguments, they should presumably be considered $x \mathrm{nPs}$ in their own right for purposes of selection. Therefore, the notion of extended projection seems to be somewhat underdetermined on such an approach.

Be that as it may, the locality conditions for contextually conditioned allomorphy would have to be formulated more leniently than assumed in Section 3.2 under the PDA in order to allow VIs to be sensitive to content outside the maximal projection of the head they realise. This might seem innocent enough for (71b), but there is a real danger of oversensitivity. Consider a possible VI like (72a). If the spell-out domain in (71b) is XP, this correctly excludes *they linguists. However, it also wrongly predicts that Pron could not be realised as they in a structure like (72b).

$$
\begin{aligned}
& \text { a. Pron }[-\mathrm{PART},+\mathrm{PL}] \leftrightarrow \text { they } /]_{\phi} \\
& \text { b. }\left[_ { \mathrm { TP } } \left[\left[_{\mathrm{PronP}} \text { they }\right]\left[{ }_{\mathrm{T}} \text {, will ... ] }\right]\right.\right.
\end{aligned}
$$

Intuitively, one might want to treat PronP in (72b) as a distinct extended projection from $\mathrm{TP}$ and limit spell-out domains from being larger than maximal projections. Apart from the question of how PronP gets to constitute a nominal extended projection on its own, this leads back to the problem that PronP should not form an independent extended projection in (71b) in order to block *they linguists. Leaving open the question of whether the locality conditions could be modified to make a specifier-based account of this type work, I consider the fact that a PDA-based account avoids such problems to be a considerable advantage. Incidentally, these considerations suggest that if the third person gap in Spanish-type languages is also a PF effect, a specifier-based analysis of their APCs structure may be more problematic than assuming a distinct PersP (see Sections 2.3 and 4.3.2).

To finish, I offer some considerations of the third person gap against the background of recent criticism of the DP hypothesis, e.g. Bruening (2009) and Van Eynde (2006). Given 
that neither author specifically addresses APCs or the third person gap, I mainly aim to point out some challenges that an NP hypothesis of English-type APCs would have to deal with.

Bruening (2009: 33) tentatively sketches an updated nP shell analysis where modifiers are introduced as specifiers of little $\mathrm{n}$ heads. While his sketch involves demonstratives, I presume that adnominal pronouns would also be assigned to a specifier position as in (73).

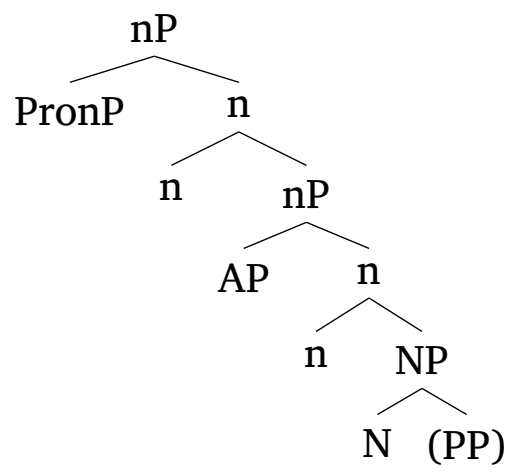

Considering that an important element of Bruening's (2009) argument against the DP analysis is the observation that selection seems to be for "nominal properties" and never for particular determiners, unaccompanied ("pronominal") demonstratives and pronouns should not be simple DemP or PronP arguments. Instead, they should only be able to occur within a nominal structure like (73), probably involving some kind of empty noun (Panagiotidis 2002) in those cases. This avoids the issues with the variable $x$ nP-status of pronouns discussed above for other specifier-based approaches and partly parallels Panagiotidis's (2015) implementation of extended projections (on an abstract level).

Of course, this is not a worked-out analysis. Some open questions concern the treatment of definite articles and the possibility of distinguishing between different specifier positions to derive word order effects and co-occurrence restrictions. If definite articles are assumed to realise some $n$-head position associated with the adnominal pronoun in the specifier, the same issues discussed for other specifier-based accounts would presumably apply here as well. Specifically, why do some languages block third person pronouns in the relevant specifier position and why would this typically correlate with the existence of an overt article? If the article corresponded to a specifier position itself, one would have to somehow ensure that articles and adnominal pronouns compete for the same specifier position (in languages like English) in order to capture their interaction. However, that alone would still not explain why pronouns can - or in the third person: have to - occur on their own, while articles cannot.

Van Eynde's (2006) analysis of Dutch nominal structure, set within the HPSG-framework, rejects the existence of functional categories, reanalysing them as instances of lexical categories like noun, pronoun or adjective. Prenominal nominal modifiers like determiners, possessives, but also complex modifiers, are uniformly treated as functors, which can impose requirements on the head via a SELECT feature (Van Eynde 2006: 164f.). ${ }^{20}$ The third person gap is not addressed in the paper, but given the lexicalist nature of the approach my understanding is that the gap could be modelled using a SELECT feature in the lexical entries of third person pronouns. Just like the lexicalist DP approach assum-

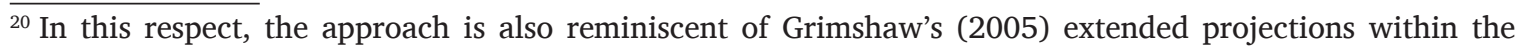
Principles and Parameters paradigm, particularly in Panagiotidis's (2015) implementation.
} 
ing a distinction between transitive and intransitive $\mathrm{D}$ heads, it does not seem like this analysis would give rise to any, even tentative, crosslinguistic inferences about expected interactions between the availability of third person pronouns and articles.

To conclude, I have argued that appositive approaches to English-type APCs do not appear to capture the third person gap or aspects of its crosslinguistic distribution. Specifier-based approaches run into similar issues when applied to English, although some languages may involve specifier structures in their APCs. A specifier-based account based on Bruening's (2009) nP-shells offers some advantages over other specifier-based analyses thanks to a clearer treatment of extended projections, but does not seem to offer a clear perspective on the English third person gap as it stands. The lexicalist approaches can capture the data, but do not appear to offer further insights into the crosslinguistic distribution.

Against this background, I stand by the hypothesis that English-type APCs are most adequately analysed as pronominal determiners heading a DP with the third person gap resulting from competition between the VIs realising the definite article and third person respectively. The observation that languages beyond Europe and adjacent areas do not generally seem to display a third person gap in APCs is in line with the view that the PDA a) does not structurally enforce the third person gap and b) is not universal, with most other configurations not expected to restrict the occurrence of third person APCs. The occurrence of a third person gap in languages like Spanish raises new questions, but does not undermine the general approach to the third person gap advocated here.

\section{Conclusion}

This paper has been concerned with APCs like we linguists and the third person gap in *they linguists in languages like English. I have argued in favour of a pronominal determiner analysis (PDA) for these languages and proposed that the third person gap in APCs is a PF effect resulting from contextually conditioned allomorphy between two possible exponents for third person D heads. Several alternative analyses of APCs structure were discussed with respect to their ability to capture the third person gap and found to be more problematic than the DP-based PDA.

Data from a crosslinguistic survey support the hypothesis that the lack of third person APCs interacts with the presence of distinct articles, although the identification of the third person gap in one group of languages not conforming to the PDA (Spanish, Galician, Bulgarian) suggests that the third person gap can also arise outside of pronominal determiner structures. It is possible that the explanation for the gap in these languages is ultimately similar to that proposed for English, but details remain for future research.

The third person gap does not seem to be crosslinguistically common and indeed may represent an areal feature of Standard Average European (and slightly beyond). In a wider typological (and potentially also historical) perspective, the observed relationship between articles and third person pronouns may also be indicative of a role for personal pronouns in the grammaticalisation of determiners (Himmelmann 1997, Himmelmann 2001: 838f. and especially Louagie \& Verstraete 2015), as also illustrated by languages in the sample where third person pronouns and articles are non-distinct (Hoava, see Palmer 2017).

If the proposed approach is on the right track, it raises further questions beyond explanatory adequacy, most notably why such an edge sensitive allomorphic distinction between "articles" and "pronouns" should occur particularly in the third person. That is, why is a similar edge-sensitive allomorphic alternation not equally common for first or second person pronouns? I have no answer to this question at present, but I can offer a speculative rationale for how this third vs. first/second person asymmetry may be sustained. While I 
am not aware of comparative studies of the relative frequencies of (third person) definite noun phrases and APCs, it seems plausible that full/lexical third person $x \mathrm{nPs}$ are more frequent in the linguistic input of learners than first or second person APCs. While this does not force third person pronouns to be sensitive to whether or not they are followed by overt material, the higher frequency of third person $x \mathrm{nPs}$ could contribute to a higher diachronic stability. An allomorphic distinction may then be more likely to survive in third person contexts because language acquirers are more likely to pick it up thanks to the larger amount of relevant data compared to non-third person APCs.

\section{Abbreviations}

\section{Glosses}

ACC $=$ accusative, $\mathrm{AUTH}=$ author, $\mathrm{CONJ}=$ conjunction, $\mathrm{DEF}=$ definite, $\mathrm{DEM}=$ demonstrative, $\mathrm{DET}=$ determiner, $\mathrm{EXCL}=$ exclusive, $\mathrm{F}=$ feminine, $\mathrm{FOC}=$ focus, $\mathrm{HON}=$ honorific, $\mathrm{INCL}=$ inclusive, $\mathrm{IPFV}=$ imperfective, $\mathrm{LOC}=$ locative, $\mathrm{M}=$ masculine, $\mathrm{N}=$ neuter, $\mathrm{NEG}=$ negative, $\mathrm{NOM}=$ nominative, $\mathrm{NUM}=$ numeral, $\mathrm{PART}=$ participant, $\mathrm{PL}=$ plural, PRS $=$ present, PURP $=$ purposive, RED $=$ reduplication, REFL $=$ reflexive, $\mathrm{SG}=$ singular, TAM $=$ tense-aspectmood marker.

\section{Acronyms}

Art $_{\mathrm{no}}=$ lacking distinct articles, Art $_{\mathrm{yes}}=$ having articles distinct from third person pronouns, $\mathrm{APC}=$ adnominal pronoun construction, $\mathrm{APC}_{3}=$ allowing third person APCs, BIC $=$ Bayesian information criterion, $\mathbf{G A P}_{3}=$ displaying a third person gap, PDA $=$ pronominal determiner analysis, $\mathrm{VI}=$ Vocabulary Item, $x \mathrm{nP}=$ extended nominal projection.

\section{Additional Files}

The additional files for this article can be found as follows:

- Supplementary file 1. Language list for 'The third person gap in adnominal pronoun constructions'. DOI: https://doi.org/10.5334/gjgl.1121.s1

- Supplementary file 2. CSV-table of crosslinguistic data used for analysis. DOI: https://doi.org/10.5334/gjgl.1121.s2

- Supplementary file 3. $\mathrm{R}$ code for statistical analysis and generation of graphics. DOI: https://doi.org/10.5334/gjgl.1121.s3

\section{Acknowledgements}

I want to thank Stavros Skopeteas for crucial advice concerning the statistical data analysis and three anonymous Glossa reviewers for their comments that helped me improve this article in many ways. Thanks also to Andreas Blümel for discussion and to Deniz Satik for comments on a draft. Moreover, many thanks to the native speakers and language experts that helped me clarify the data situation for individual languages. Any problems, mistakes or misinterpretations in this article are my responsibility.

\section{Funding Information}

I gladly acknowledge support by the German Research Foundation and the Open Access Publication Fund of the University of Göttingen for the publication of this article. Parts of the database used here were collected while working on the ReCoS-project (European Research Council Advanced Grant No. 269752 "Rethinking Comparative Syntax", PI: Ian Roberts).

\section{Competing Interests}

The author has no competing interests to declare. 


\section{References}

Abney, Steven. 1987. The English noun phrase in its sentential aspect. Boston, MA: MIT dissertation.

Ackema, Peter \& Ad Neeleman. 2013. Subset controllers in agreement relations. Morphology 23. 291-323. DOI: https://doi.org/10.1007/s11525-013-9218-4

Ackema, Peter \& Ad Neeleman. 2018. Features of person. Cambridge, MA: MIT Press. DOI: https://doi.org/10.7551/mitpress/11145.001.0001

Acquaviva, Paolo. 2009. Roots and lexicality in distributed morphology. In Alexandra Galani, Daniel Redinger \& Norman Yeo (eds.), York Papers in Linguistics Series 2 special issue - York-Essex Morphology Meeting, 1-21. York: University of York. http://www. york.ac.uk/language/ypl/ypl2issue10/YPL10_YEMM_01_Acquaviva.pdf.

Arregi, Karlos \& Andrew Ira Nevins. 2013. Contextual neutralization and the Elsewhere Principle. In Ora Matushansky \& Alec Marantz (eds.), Distributed morphology today: Morphemes for Morris Halle, 199-221. Cambridge, MA: MIT Press. DOI: https://doi. org/10.7551/mitpress/9780262019675.001.0001

Asbury, Anna. 2008. The morphosyntax of case and adpositions. Utrecht: University of Utrecht dissertation.

Bárány, András. 2017. Person, case, and agreement: The morphosyntax of inverse agreement and global case splits. Oxford: Oxford University Press. DOI: https://doi.org/10.1093/ oso/9780198804185.003.0001

Bates, Douglas, Martin Mächler, Ben Bolker \& Steve Walker. 2015. Fitting linear mixedeffects models using lme4. Journal of Statistical Software 67(1). 1-48. DOI: https://doi. org/10.18637/jss.v067.i01

Bauer, Winifred. 1993. Maori. London: Routledge. DOI: https://doi.org/10.4324/9780 203403723

Becker, Richard A., Allan R. Wilks \& Ray Brownrigg. 2016. mapdata: Extra Map Databases. R package version 2.2-6; Original S code by Richard A. Becker and Allan R. Wilks. R version by Ray Brownrigg. https://CRAN.Rproject.org/package = mapdata.

Benveniste, Emile. 1971. The nature of pronouns. In Problems in general linguistics, 217222. Coral Gables (FL): University of Miami Press.

Bernstein, Judy B. 2008a. English th-forms. In Henrik Høeg Müller \& Alex Klinge (eds.), Essays on nominal determination: From morphology to discourse management, 213-232. Amsterdam: John Benjamins. DOI: https://doi.org/10.1075/slcs.99.12ber

Bernstein, Judy B. 2008b. Reformulating the determiner phrase analysis. Language and Linguistics Compass 2(6). 1246-1270. DOI: https://doi.org/10.1111/j.1749-818X.2008. 00091.x

Besnier, Niko. 2000. Tuvaluan. London: Routledge. DOI: https://doi.org/10.4324/9780 203027127

Blake, Barry J. 2001. The noun phrase in Australian languages. In Jane Simpson, David Nash, Mary Laughren, Peter Austin \& Barry Alpher (eds.), Forty years on. Ken Hale and Australian languages, 415-425. Canberra: Pacific Linguistics.

Bobaljik, Jonathan David. 2000. The ins and outs of contextual allomorphy. In K. Grohmann \& C. Struijke (eds.), University of Maryland Working Papers in Linguistics, 35-71. College Park, MD: University of Maryland.

Bobaljik, Jonathan David. 2012. Universals in comparative morphology. Suppletion, superlatives, and the structure of words. Cambridge, MA: MIT Press. DOI: https://doi. org/10.7551/mitpress/9069.001.0001

Borg, Albert \& Marie Azzopardi-Alexander. 1997. Maltese. London: Routledge. DOI: https://doi.org/10.4324/9780203192603 
Bosch, Peter \& Carla Umbach. 2007. Reference determination for demonstrative pronouns. In Dagmar Bittner \& Natalia Gargarina (eds.), Intersentential pronominal reference in child and adult language (ZAS Papers in Linguistics 48), 39-51. Berlin: Zentrum für Allgemeine Sprachwissenschaft.

Bosch, Peter, Graham Katz \& Carla Umbach. 2007. The non-subject bias of German demonstrative pronouns. In Monika Schwarz-Friesel, Manfred Consten \& Mareile Knees (eds.), Anaphors in text: cognitive, formal and applied approaches to anaphoric reference, 145-164. Amsterdam: John Benjamins. DOI: https://doi.org/10.1075/slcs.86.13bos

Bosch, Peter \& Stefan Hinterwimmer. 2016. Anaphoric reference by demonstrative pronouns in German. In Anke Holler \& Katja Suckow (eds.), Empirical perspectives on anaphora resolution, 193-212. Berlin: De Gruyter.

Bosch, Peter, Tom Rozario \& Yufan Zhao. 2003. Demonstrative pronouns and personal pronouns. German der vs. er. In Proceedings of the EACL2003. Quoted after manuscript version available on http://homepages.abdn.ac.uk/k.vdeemter/pages/bosch.pdf, accessed 27 November 2015.

Bošković, Željko. 2008. What will you have, DP or NP? In Proceedings of NELS 37. Amherst: GLSA.

Bošković, Željko. 2015. On second position clitics crosslinguistically. Ms., University of Connecticut. Available on http://web.uconn.edu/boskovic/OresnikCliticsRefrences. pdf, accessed 15 February 2016. DOI: https://doi.org/10.1075/la.236.02bos

Bruening, Benjamin. 2009. Selectional asymmetries between CP and DP suggest that the DP hypothesis is wrong. In Laurel MacKenzie (ed.), Proceedings of the 31st Annual Penn Linguistics Colloquium, vol. 15 (U. Penn Working Papers in Linguistics), 27-35. Philadelphia, PA.

Burton-Roberts, Noel. 1975. Nominal apposition. Foundations of Language 13. 391-419.

Cardinaletti, Anna. 1994. On the internal structure of pronominal DPs. The Linguistic Review 11. 195-219. DOI: https://doi.org/10.1515/tlir.1994.11.3-4.195

Cardinaletti, Anna \& Michal Starke. 1999. The typology of structural deficiency: a case study of the three classes of pronouns. In Henk van Riemsdijk (ed.), Clitics in the languages of Europe, 145-233. Berlin, New York: Mouton de Gruyter. DOI: https://doi. org/10.1515/9783110804010.145

Choi, Jaehoon. 2013. Pro-drop in pronoun-noun constructions. In Stefan Keine \& Shayne Sloggett (eds.), NELS 42: Proceedings of the 42nd meeting of the North East Linguistic Society, 119-128. Amherst, MA: GLSA.

Choi, Jaehoon. 2014a. Pronoun-noun constructions and the syntax of DP. Tucson, AZ: University of Arizona dissertation.

Choi, Jaehoon. 2014b. The locus of person feature and agreement. In Hsin-Lun Huang, Ethan Poola \& Amanda Rysling (eds.), NELS 43: Proceedings of the 43rd meeting of the North East Linguistic Society, 65-76. Amherst, MA: GLSA.

Chomsky, Noam. 2001. Derivation by phase. In Michael Kenstowicz (ed.), Ken Hale. A life in language, 1-52. Cambridge, MA: MIT Press.

Collins, Chris (ed.). 2014. Cross-linguistic studies of imposters and pronominal agreement. Oxford: Oxford University Press. DOI: https://doi.org/10.1093/acprof:oso/9780199 336852.001.0001

Collins, Chris \& Paul Postal. 2012. Imposters: a study in pronominal agreement. Cambridge, MA: MIT Press. DOI: https://doi.org/10.7551/mitpress/9780262016889.001.0001

Comrie, Bernard. 2000. Pragmatic binding: demonstratives as anaphors in dutch. In Matthew L. Judge \& Jeri L. Moxley (eds.), Proceedings of the twenty-third annual meeting of the Berkeley Linguistics Society: General session and parasession on pragmatics and 
grammatical structure (1997), 50-61. Berkeley, CA: Berkeley Linguistics Society. DOI: https://doi.org/10.3765/bls.v23i1.1281

Corbett, Greville G. 2006. Agreement. Cambridge: Cambridge University Press. DOI: https://doi.org/10.2307/20459614

Cornilescu, Alexandra \& Alexandru Nicolae. 2014. Classifying pronouns: The view from Romanian. Bucharest Working Papers in Linguistics 16(1). 5-33.

Danon, Gabi. 2001. Syntactic definiteness in the grammar of Modern Hebrew. Linguistics 39(6). 1071-1116. DOI: https://doi.org/10.1515/ling.2001.042

Danon, Gabi. 2008. Definiteness spreading in the Hebrew construct state. Lingua 118. 872-906. DOI: https://doi.org/10.1016/j.lingua.2007.05.012

Danon, Gabi. 2010. The definiteness feature at the syntax-semantics interface. In Anna Kibort \& Greville G. Corbett (eds.), Features. Perspectives on a key notion in linguistics, 143-165. Oxford: Oxford University Press. DOI: https://doi.org/10.1093/acprof: oso/9780199577743.003.0006

Déchaine, Rose-Marie \& Martina Wiltschko. 2002. Decomposing pronouns. Linguistic Inquiry 33(3). 409-442. DOI: https://doi.org/10.1162/002438902760168554

Delorme, Evelyn \& Ray C. Dougherty. 1972. Appositive NP constructions. Foundations of Language 8. 2-29.

den Dikken, Macel. 2018. Dependency and directionality. Cambridge: Cambridge University Press. DOI: https://doi.org/10.1017/9781316822821

Diessel, Holger. 1999. Demonstratives. Form, function, and grammaticalization. Amsterdam: John Benjamins. DOI: https://doi.org/10.1075/tsl.42

Dryer, Matthew S. 1989. Large linguistic areas and language sampling. Studies in Language 13(2). 257-292. DOI: https://doi.org/10.1075/sl.13.2.03dry

Dryer, Matthew S. \& Martin Haspelmath (eds.). 2013. WALS online. Leipzig: Max Planck Institute for Evolutionary Anthropology. http://wals.info/.

Einarsson, Stefán. 1961. Icelandic. Grammar, texts, glossary. 4th reprint. Baltimore, MD: John Hopkins Press.

Elbourne, Paul. 2005. Situations and individuals. Cambridge, MA: MIT Press.

Embick, David. 1997. Voice and the interfaces of syntax. Philadelphia, PA: University of Pennsylvania dissertation.

Embick, David. 2010. Localism versus globalism in morphology and phonology. Cambridge, MA: MIT Press. DOI: https://doi.org/10.7551/mitpress/9780262014229.001.0001

Embick, David \& Alec Marantz. 2008. Architecture and blocking. Linguistic Inquiry 39. 1-53. DOI: https://doi.org/10.1162/ling.2008.39.1.1

Embick, David \& Rolf Noyer. 2001. Movement operations after syntax. Linguistic Inquiry 32(4). 555-595. DOI: https://doi.org/10.1162/002438901753373005

Engel, Ulrich. 1996. Deutsche Grammatik. Heidelberg: Julius Groos Verlag.

Evans, Nicholas D. 1995. A grammar of Kayardild. Berlin: Mouton de Gruyter. DOI: https:// doi.org/10.1515/9783110873733

Faraclas, Nicholas G. 1996. Nigerian Pidgin. London: Routledge. DOI: https://doi.org/ 10.4324/9780203192801

Fassi-Fehri, Abdelkader. 1999. Arabic modifying adjectives and DP structures. Studia Linguistica 53(2). 105-154. DOI: https://doi.org/10.1111/1467-9582.00042

Frajzyngier, Zygmunt. 1993. A grammar of Mupun. Berlin: Dietrich Reimer Verlag. DOI: https://doi.org/10.1515/9783110893908

Furuya, Kaori. 2008. DP hypothesis for Japanese "bare" noun phrases. In Łukasz Abramowicz, Stefanie Brody, Toni Cook, Ariel Diertani, Aviad Eilam, Keelan Evanini, Kyle Gorman, Laurel MacKenzie \& Joshua Tauberer (eds.), Proceedings of the 31st 
Annual Penn Linguistics Colloquium, vol. 14 (U. Penn Working Papers in Linguistics), 149-162. Philadelphia, PA: University of Pennsylvania.

Furuya, Kaori. 2017. Two types of the 3rd person feature in English?! Ampersand 4. 40-46. DOI: https://doi.org/10.1016/j.amper.2017.06.002

Gardiner, S. C. 1984. Old Church Slavonic. An elementary grammar. Cambridge: Cambridge University Press. DOI: https://doi.org/10.2307/3729689

Gary, Judith Olmsted \& Gamal-Eldin. 1982. Cairene Egyptian Colloquial Arabic. London: Croom Helm. DOI: https://doi.org/10.2307/604143

Grimshaw, Jane. 2005. Extended projection. In Words and structure, chap. 1, 1-71. Revision of the 1991 manuscript. Stanford, CA: CSLI Publications.

Gröndahl, Tommi. 2015a. Määräisyys funktionaalisena pääsanana suomen kielen nominilausekkeessa (Definiteness as a functional head in the Finnish noun phrase). Helsinki: University of Helsinki MA thesis.

Gröndahl, Tommi. 2015b. The DP-structure of the Finnish noun phrase. Presentation at the XIIth International Congress for Finno-Ugric Studies (CIFU XII), 19 August 2015, Oulu.

Halle, Morris. 1997. Distributed morphology: Impoverishment and fission. In Benjamin Bruening, Yoonjung Kang \& Martha McGinnis (eds.), MITWPL 30: Papers at the interface, 425-449. Cambridge, MA: MIT Working Papers in Linguistics. DOI: https:// doi.org/10.1075/cilt.202.07hal

Halle, Morris \& Alec Marantz. 1993. Distributed Morphology and the pieces of inflection. In Kenneth Hale \& Samuel Jay Keyser (eds.), The View from Building 20, 111-176. Cambridge, MA: MIT Press.

Hammarström, Harald, Robert Forkel, Martin Haspelmath \& Sebastian Bank. 2020. Glottolog 4.2.1. Max Planck Institute for the Science of Human History. Jena. https:// glottolog.org/\%20accessed\%202020-05-04.

Harbour, Daniel. 2016. Impossible persons. Cambridge, MA: MIT Press. DOI: https://doi. org/10.7551/mitpress/9780262034739.001.0001

Harley, Heidi \& Elizabeth Ritter. 2002. Person and number in pronouns: a feature-geometric analysis. English. Language 78(3). 482-526. DOI: https://doi.org/10.1353/ lan.2002.0158

Harley, Heidi \& Rolf Noyer. 1999. State-of-the-article: Distributed morphology. GLOT 4(4). 3-9.

Harris, Martin. 1991. Demonstrative adjectives and pronouns in a Devonshire dialect. In Peter Trudgill \& J. K. Chambers (eds.), Dialects of English: Studies in grammatical variation, 20-28. London: Longman. DOI: https://doi.org/10.4324/9781315505459-4

Haspelmath, Martin. 2001. The European linguistic area: Standard Average European. In Martin Haspelmath, Ekkehard König, Wolfgang Oesterreicher \& Wolfgang Raible (eds.), Language typology and language universals. An international handbook 2. 14921510. Berlin: Mouton de Gruyter. DOI: https://doi.org/10.1515/9783110171549.2.1 4.1492

Hazen, Kirk, Sarah Hamilton \& Sarah Vacovsky. 2011. The fall of demonstrative them. Evidence from Appalachia. English World-Wide 32(1). 74-103. DOI: https://doi. org/10.1075/eww.32.1.04haz

Heim, Irene. 2008. Features on bound pronouns. In Daniel Harbour, David Adger \& Susana Béjar (eds.), Phi theory. Phi-Features across modules and interfaces, 35-56. Oxford, New York: Oxford University Press.

Heine, Bernd \& Tania Kuteva. 2005. Language contact and grammatical change. Cambridge: Cambridge University Press. DOI: https://doi.org/10.1017/CBO9780511614132 
Helbig, Gerhard \& Joachim Buscha. 2001. Deutsche Grammatik. Ein Handbuch für den Ausländerunterricht. Leipzig: Langenscheidt.

Hewitt, B. George. 1989. Abkhaz. First published in 1979 by North-Holland Publishing Company. London: Routledge. DOI: https://doi.org/10.1016/B0-08-044854-2/04622-8

Heycock, Caroline \& Roberto Zamparelli. 2005. Friends and colleagues: Plurality, coordination, and the structure of DP. Natural Language Semantics 13. 201-270. DOI: https:// doi.org/10.1007/s11050-004-2442-z

Himmelmann, Nikolaus P. 1997. Deiktikon, Artikel, Nominalphrase: Zur Emergenz synaktischer Struktur. Tübingen: Niemeyer. DOI: https://doi.org/10.1515/9783110929621

Himmelmann, Nikolaus P. 2001. Articles. In Martin Haspelmath, Ekkehard König, Wolfgang Oesterreicher \& Wolfgang Raible (eds.), Language typology and language universals. An international handbook, 831-841. Berlin: Mouton de Gruyter. DOI: https://doi.org/10.4324/9781315307190-3

Hinterwimmer, Stefan. 2015. A unified account of the properties of German demonstrative pronouns. In P. Grosz, P. Patel-Grosz \& I. Yanovich (eds.), The proceedings of the workshop on pronominal semantics at NELS40, 61-107. Amherst, MA: GLSA Publications.

Hinterwimmer, Stefan \& Peter Bosch. 2016. Demonstrative pronouns and perspective. In Patrick Grosz \& Pritty Patel-Grosz (eds.), The impact of pronominal form on interpretation, 189-220. Berlin: Mouton de Gruyter.

Höhn, Georg F. K. 2016. Unagreement is an illusion: Apparent person mismatches and nominal structure. Natural Language and Linguistic Theory 34(2). 543-592. DOI: https:// doi.org/10.1007/s11049-015-9311-y

Höhn, Georg F. K. 2017. Non-possessive person in the nominal domain. Cambridge: University of Cambridge dissertation.

Höhn, Georg F. K., Giuseppina Silvestri \& M. Olimpia Squillaci. 2016. Unagreement between Italian and southern Italian dialects. Rivista di Grammatica Generativa 38. 137-147.

Höhn, Georg F. K., Giuseppina Silvestri \& M. Olimpia Squillaci. 2017. Greek and Romance unagreement in Calabria. Journal of Greek Linguistics 17(2). 263-292. DOI: https://doi. org/10.1163/15699846-01702002

Holton, Gary. 2014. Western Pantar. In Antoinette Schapper (ed.), The Papuan languages of Timor, Alor and Pantar: volume 1. Sketch grammars, 23-95. Berlin: Mouton de Gruyter.

Hurtado, Alfredo. 1985. The unagreement hypothesis. In L. King \& C. Maley (eds.), Selected papers from the thirteenth linguistic symposium on Romance languages, 187-211. Amsterdam: John Benjamins. DOI: https://doi.org/10.1075/cilt.36.12hur

Huttar, George L. \& Mary L. Huttar. 1994. Ndyuka. London: Routledge. DOI: https://doi. org/10.4324/9780203214824

Inokuma, Sakumi. 2009. So-called pronoun-noun construction in Japanese: A new perspective on nominal syntax. Linguistic Research 25. 31-42.

Joenpelto, Eeva. 1982. Elämän rouva, rouva Glad. Helsinki: Werner Söderström Osakeyhtiö. DOI: https://doi.org/10.2307/40138057

Johannessen, Janne Bondi. 2008. The pronominal psychological demonstrative in Scandinavian: Its syntax, semantics and pragmatics. Nordic Journal of Linguistics 31(2). 161-192. DOI: https://doi.org/10.1017/S0332586508001923

Julien, Marit. 2005. Nominal phrases from a Scandinavian perspective. Amsterdam: John Benjamins. DOI: https://doi.org/10.1075/la.87

Keesing, Roger M. 1985. Kwaio grammar (Pacific Linguistics 88). Canberra: The Australian National University. 
Lawrenz, Birgit. 1993. Apposition. Begriffsbestimmung und syntaktischer Status. Tübingen: Narr.

Lekakou, Marika \& Kriszta Szendrói. 2007. Eliding the noun in close apposition, or Greek polydefinites revisited. UCL Working Papers in Linguistics 19. 129-154.

Lekakou, Marika \& Kriszta Szendrői. 2012. Polydefinites in Greek: Ellipsis, close apposition and expletive determiners. Journal of Linguistics 48. 107-149. DOI: https://doi. org/10.1017/S0022226711000326

Lichtenberk, Frantisek. 2000. Inclusory pronominals. Oceanic Linguistics 39. 1-32. DOI: https://doi.org/10.1353/ol.2000.0006

Longobardi, Guiseppe. 1994. Reference and proper names: A theory of N-movement in syntax and logical form. Linguistic Inquiry 25(4). 609-665.

Longobardi, Guiseppe. 2008. Reference to individuals, person, and the variety of mapping parameters. In Henrik Høeg Müller \& Alex Klinge (eds.), Essays on nominal determination: From morphology to discourse management, 189-211. Amsterdam: John Benjamins. DOI: https://doi.org/10.1075/slcs.99.11lon

Louagie, Dana \& Jean-Christophe Verstraete. 2015. Personal pronouns with determining functions in Australian languages. Studies in Language 39(1). 159-198. DOI: https:// doi.org/10.1075/sl.39.1.06lou

Luján, Marta. 2000. Determiners as modified pronouns. In Arika Okrent \& John Boyle (eds.), Chicago Linguistic Society, vol. 1: The main session, 259-273. Chicago, IL: Chicago Linguistic Society.

Luján, Marta. 2002. Determiners as modified pronouns. CÍRCULO de Lingüística Aplicada a la Comunicación (CLAC) 9. 19-34.

Lyons, Christopher. 1999. Definiteness. Cambridge: Cambridge University Press. DOI: https://doi.org/10.1017/CBO9780511605789

Maček, Dora. 1995. The development and function of the dialectal them. Studia Romanica et Anglica Zagrabiensia 40. 221-235.

Mallinson, Graham. 1986. Rumanian. London: Croom Helm.

Marantz, Alec. 2009. Phases and words. Unpublished ms., NYU.

Nevins, Andrew. 2007. The representation of third person and its consequences for person-case effects. Natural Language \& Linguistic Theory 25(2). 273-313. DOI: https:// doi.org/10.1007/s11049-006-9017-2

Nevins, Andrew. 2011. Multiple agree with clitics: Person complementarity vs. omnivorous number. Natural Language \& Linguistic Theory 29. 939-971. DOI: https://doi. org/10.1007/s11049-011-9150-4

Newman, Paul. 2000. The Hausa language. An encyclopedic reference grammar. New Haven, CT: Yale University Press. DOI: https://doi.org/10.2307/3087661

Noguchi, Tohru. 1997. Two types of pronouns and variable binding. Language 73. 770797. DOI: https://doi.org/10.2307/417326

Olsen, Susan. 1991. Die deutsche Nominalphrase als Determinansphrase. In DET, COMP und INFL: Zur Syntax funktionaler Kategorien und grammatischer Funktionen, 35-56. Tübingen: Niemeyer. DOI: https://doi.org/10.1515/9783111353838.35

Palmer, Bill. 2008. Kokota grammar (Oceanic Linguistics Special Publication 35). Honolulu, HI: University of Hawai'i Press. DOI: https://doi.org/10.1515/9780824863258

Palmer, Bill. 2017. Categorial flexibility as an artefact of the analysis. Pronouns, articles and the DP in Hoava and Standard Fijian. Studies in Language 41(2). 408-444. DOI: https://doi.org/10.1075/sl.41.2.05pal

Panagiotidis, Phoevos. 2002. Pronouns, clitics and empty nouns. Amsterdam: John Benjamins. DOI: https://doi.org/10.1075/la.46 
Panagiotidis, Phoevos. 2011. Categorial features and categorizers. The Linguistic Review 28. 365-386. DOI: https://doi.org/10.1515/tlir.2011.010

Panagiotidis, Phoevos. 2015. Categorial features. A generative theory of word class categories. Cambridge: Cambridge University Press. DOI: https://doi.org/10.1017/CBO97811 39811927

Panagiotidis, E. Phoevos \& Theodore Marinis. 2011. Determiner spreading as DPpredication. Studia Linguistica 65(3). 268-298. DOI: https://doi.org/10.1111/j.14679582.2011.01186.x

Parrott, Jeffrey K. 2009. Danish vestigial case and the acquisition of vocabulary in distributed morphology. Biolinguistics 3(2-3). 270-304.

Paul, Ileana \& Lisa deMena Travis. to appear. Augmented pronoun constructions in Malagasy across time and space. In Proceedings of CLS2018.

Payne, John \& Rodney Huddleston. 2002. Nouns and noun phrases. In Rodney Huddleston \& Geoffrey K. Pullum (eds.), The Cambridge grammar of English, chap. 5, 323-52. Cambridge: Cambridge University Press. DOI: https://doi.org/10.1017/9781316423530.006

Pedersen, Thomas Lin \& Fabio Crameri. 2018. scico: Colour Palettes Based on the Scientific Colour-Maps. R package version 1.1.0. https://CRAN.Rproject.org/package = scico.

Pereltsvaig, Asya. 2006. Head movement in Hebrew nominals: A reply to Shlonsky. Lingua 116. A1-A40. DOI: https://doi.org/10.1016/j.lingua.2005.11.001

Pereltsvaig, Asya. 2013. Noun phrase structure in article-less Slavic languages: DP or not DP? Language and Linguistics Compass 7(3). 201-219. DOI: https://doi.org/10.1111/ lnc3.12014

Pesetsky, David. 1978. Category switching and so-called so-called pronouns. In Donka Farkas, Wesley M. Jacobsen \& Karol W. Todrys (eds.), Chicago Linguistic Society 14. 350-360. Chicago, IL: Chicago Linguistic Society.

Postal, Paul. 1969. On so-called "pronouns" in English. In David A. Reibel \& Sanford A. Schane (eds.), Modern studies in English: Readings in Transformational Grammar, 201-226. Englewood Cliffs, NJ: Prentice Hall.

R Core Team. 2020. R: A Language and Environment for Statistical Computing. R Foundation for Statistical Computing. Vienna, Austria. https://www.R-project.org/.

Radford, Andrew. 1993. Head-hunting: On the trail of the nominal Janus. In Greville G. Corbett, Norman M. Fraser \& Scott McGlashan (eds.), Heads in grammatical theory, chap. 5. 73-113. Cambridge: Cambridge University Press. DOI: https://doi.org/10.1017/ CBO9780511659454.005

Radford, Andrew. 2009. An introduction to English syntax. Cambridge: Cambridge University Press.

Rauh, Gisa. 2003. Warum wir Linguisten "euch Linguisten", aber nicht "sie Linguisten" akzeptieren können. Eine personendeiktische Erklärung. Linguistische Berichte 196. 390-424.

Rauh, Gisa. 2004. Warum 'Linguist' in 'ich/du Linguist' kein Schimpfwort sein muß. Eine konversationstheoretische Erklärung. Linguistische Berichte 197. 77-105.

Rennison, John R. 1997. Koromfe. London: Routledge. DOI: https://doi.org/10.4324/ 9781315005164

Richards, Marc. 2008. Defective agree, case alternations, and the prominence of person. In Marc Richards \& Andrej L. Malchukov (eds.), Scales, 137-161. Leipzig: Universität Leipzig.

Roehrs, Dorian. 2005. Pronouns are determiners after all. In Marcel den Dikken \& Christina M. Tortora (eds.), The function of function words and functional categories, 251-285. Amsterdam: John Benjamins. DOI: https://doi.org/10.1075/la.78.10roe 
RStudio Team. 2020. RStudio: Integrated Development Environment for R. Boston, MA: RStudio, Inc. http://www.rstudio.com/.

Rutkowski, Pawel. 2002. Noun/pronoun asymmetries: evidence in support of the DP hypothesis in polish. Jezikoslovlje 3(1-2). 159-170.

Saab, Andrés. 2007. Anti-agreement effects and null subjects in Spanish: A distributed morphology approach. Handout from IV Encuentro de Gramática Generativa, Mendoza, Argentina, July 26-28 2007.

Saab, Andrés. 2013. Anticoncordancia y sincretismo en Español. Unagreement and syncretism in Spanish. Lingüística 29(2). 191-229.

Seiler, Walter. 1985. Imonda, a Papuan language (Pacific Linguistics 93). Canberra: The Australian National University.

Shlonsky, Ur. 2004. The form of Semitic noun phrases. Lingua 114. 1465-1526. DOI: https://doi.org/10.1016/j.lingua.2003.09.019

Sigurðsson, Halldór Ármann \& Jim Wood. 2020. "We Olaf”: Pro[(x-)NP] constructions in Icelandic and beyond. Glossa 5(1). 16. DOI: https://doi.org/10.5334/gjgl.1054

Simon, Horst J. 2007. Wie Höflichkeit die Person(en) verwirrt - und wie's die Grammatik wieder ordnet. In Irmtraud Behr, Anne Larrory \& Gunhild Samson (eds.), Der Ausdruck der Person im Deutschen, 57-72. Tübingen: Stauffenburg Verlag.

Sommerstein, Alan H. 1972. On the so-called definite article in English. Linguistic Inquiry 3. 197-209.

Stavrou, Melita. 1995. Epexegesis vs. apposition in Modern Greek. In Scientific bulletin of the School of Philology 5. 217-250. Thessaloniki: Aristotle University.

Stirling, Lesley. 2008. "Double reference" in Kala Lagaw Ya narratives. In Ilana Mushin \& Brett Baker (eds.), Discourse and grammar in Australian languages, 167-202. Amsterdam: John Benjamins. DOI: https://doi.org/10.1075/slcs.104.10sti

Stirling, Lesley \& Brett Baker. 2007. Pronominal apposition and the status of 'determiner' in Australian languages. Handout from Workshop on Definiteness \& Referentiality, Australian Linguistic Conference, Adelaide, 28-30 September 2007.

Sulkala, Helena \& Merja Karjalainen. 1992. Finnish. London: Routledge. DOI: https:// doi.org/10.4324/9780203404133

Van Eynde, Frank. 2006. NP-internal agreement and the structure of the noun phrase. Journal of Linguistics 42. 1. DOI: https://doi.org/10.1017/S0022226705003713

Wickham, Hadley. 2016. ggplot2: Elegant graphics for data analysis. New York: Springer. https://ggplot2.tidyverse.org. DOI: https://doi.org/10.1007/978-3-319-24277-4

Willim, Ewa. 2000. On the grammar of Polish nominals. In Roger Martin, David Michaels \& Juan Uriagereka (eds.), Step by step: Essays on minimalist syntax in honor of Howard Lasnik, 319-343. Cambridge, MA: MIT Press.

Wiltschko, Martina. 1998. On the syntax and semantics of (relative) pronouns and determiners. Journal of Comparative Germanic Linguistics 2. 143-181. DOI: https://doi. org/10.1023/A:1009719229992

Wiltschko, Martina. 2008. The syntax of non-inflectional plural marking. Natural Language \& Linguistic Theory 26. 639-694. DOI: https://doi.org/10.1007/s11049-008-9046-0

Wiltschko, Martina. 2014. The universal structure of categories. Towards a formal typology. Cambridge: Cambridge University Press. DOI: https://doi.org/10.1017/CBO9781139 833899 
How to cite this article: Höhn, Georg F. K. 2020. The third person gap in adnominal pronoun constructions. Glossa: a journal of general linguistics 5(1): 69.1-43. DOI: https://doi.org/10.5334/gjgl.1121

\section{Submitted: 01 October 2019 Accepted: 14 April 2020 Published: 16 July 2020}

Copyright: $\odot 2020$ The Author(s). This is an open-access article distributed under the terms of the Creative Commons Attribution 4.0 International License (CC-BY 4.0), which permits unrestricted use, distribution, and reproduction in any medium, provided the original author and source are credited. See http://creativecommons.org/licenses/by/4.0/.

$\mathrm{u}[\quad$ Glossa: a journal of general linguistics is a peer-reviewed open access journal published by Ubiquity Press. 